\title{
Reforma rolna po drugiej wojnie światowej. Ustawodawstwo państwa polskiego
}

\section{ZAGADNIENIA OGÓLNE}

Geneza reform rolnych (agrarnych) w Europie Środkowej sięga XIX wieku. Były one związane ze zniesieniem poddaństwa osobistego oraz pańszczyzny, oczynszowaniem, a ostatecznie z uwłaszczeniem chłopów, czyli nadaniem im prawa własności do ziemi, zwykle uprzednio przez nich użytkowanej. W związku $\mathrm{z}$ tym reformy wiązały się jeszcze $\mathrm{z}$ okresem średniowiecza, co w praktyce na ziemiach polskich oznaczało osadnictwo wiejskie. Konsekwencje prawne tych reform, nie tylko z XIX wieku, można znaleźć współcześnie na obszarze państwa polskiego. W szczególności dotyczy to po dzień dzisiejszy istniejących wspólnot gruntowych, które powstały niekiedy za panowania króla Kazimierza Wielkiego ${ }^{1}$. I mimo przeprowadzenia reformy rolnej, zapoczątkowanej przez dekret z 1944 r., nadal działają, a obecnie ich sytuację prawną reguluje ustawa z dnia 29 czerwca 1963 r. o zagospodarowaniu wspólnot gruntowych ${ }^{2}$. Zresztą współcześnie sprawy uwłaszczenia chłopów w XIX w. znalazły się na wokandach sądów powszechnych, w tym najważniejszych instytucji sądowych w państwie, tzn. Sądu Najwyższego i Trybunału Konstytucyjnego. I co istotne, orzecznictwo tych instytucji

${ }^{1}$ Zob. H. Świątkowski, Niektóre zagadnienia prawne wspólnot gruntowych w Polsce, „Przegląd Ustawodawstwa Gospodarczego" 1958, nr 9; L. Jastrzębski, Sytuacja prawna wspólnot gruntowych w Polsce Ludowej, Warszawa 1963; J. Paliwoda, Przebudowa ustroju rolnego. Zakres dziatania administracji rolnej, Warszawa 1964, s. 243-246; M. Ptaszyk, Spółki do zagospodarowania wspólnot gruntowych - sytuacja prawna, funkcjonowanie, perspektywy (stan prawny na dzień 1 I 1985), Kraków 1989; J. Szachułowicz, Status prawny wspólnot gruntowych, „Przegląd Sądowy” $2002, \mathrm{nr} 9$.

${ }^{2}$ Dz.U. z 1963 r. nr 28 poz. 169 ze zm. 
było ze sobą sprzeczne. Sprawa zaś dotyczyła prawa połowu ryb, przyznanego na podstawie regulacji uwłaszczeniowych na obszarze dawnego Królestwa Kongresowego, a konkretnie uprawnień przyznanych na podstawie ukazu cara Aleksandra II z 1864 r. o urządzeniu włościan w Królestwie Polskim³ .

Dlatego na wstępie należy zwrócić uwagę na węzłowe zagadnienia dotyczące reform agrarnych w XIX w., a także omówić przebieg reformy rolnej przed wybuchem drugiej wojny światowej. W celu oczyszczenia przedpola dla dalszych rozważań konieczne jest zwrócenie uwagi na przesłanki, które były związane $\mathrm{z}$ przeprowadzaniem reform rolnych. Po pierwsze, regulacje prawne $\mathrm{w}$ okresie zaborów były zasadniczo wydawane w latach 1807 - 1864. Reformy rolne przebiegały w inny sposób na obszarze państwa polskiego, pod trzema zaborami, a co za tym idzie w innych warunkach politycznych. Kolejno wydawanie podstawowych aktów prawnych datuje się w: Prusach na lata 1807 - 1850; Austrii na lata 1848 - 1853; Rosji 1861 - 1910/1911; w Królestwie Polskim był to zasadniczo wspominany wyżej ukaz $1864 \mathrm{r}^{4}{ }^{4}$ A zatem przebudowy struktury obszarów wiejskich dokonano na czterech obszarach ${ }^{5}$. Reformy rolne stanowiły przejście z epoki feudalizmu do kształtującej się gospodarki kapitalistycznej. Przebieg ich związany był przede wszystkim z:

1) indemnizacją, czyli odszkodowaniem na rzecz obszarnika, które płaciło państwo albo rolnik, za pośrednictwem instytucji bankowych; spłata należności była rozłożona na szereg lat;

2) separacją - podziałem gruntów użytkowanych jednocześnie przez obszarnika i gromady;

3) regulacją serwitutów, czyli dawnym prawem do korzystania z gruntów folwarcznych i chłopskich, które przysługiwało wzajemnie chłopom i dziedzicom,

${ }^{3}$ Zob. R. Jastrzębski, Z orzecznictwa Trybunału Konstytucyjnego (prawo połowu przyznane na podstawie regulacji uwłaszczeniowych z XIX wieku na obszarze dawnego Królestwa Kongresowego). Glosa do postanowienia z 7 V 2008, SK 14/06, „Państwo i Prawo” 2010, z. 1; R. Jastrzębski, Wykładnia historyczna we wspótczesnej judykaturze, „Przegląd Sądowy” 2010, nr 1.

${ }^{4}$ Zob. Historia Państwa i Prawa Polski, t. III: Od rozbiorów do uwłaszczenia, red. J. Bardach, M. Senkowska-Gluck, red. ogólna J. Bardach, Warszawa 1981, s. 593 i n.; K. Grzybowski, Historia Państwa i Prawa Polski, t. IV: Od uwłaszczenia do odrodzenia państwa, red. ogólna J. Bardach, Warszawa 1982, s. 98-110; 326-339.

5 Szerzej: J. Rutkowski, Historia gospodarcza Polski, t. II: Czasy porozbiorowe do 1918 roku, Poznań 1950, s. 15-82; S. Kieniewicz, Przemiany społeczne i gospodarcze w Królestwie Polskim (1815-1830). Wybór tekstów źródłowych, Warszawa 1951, s. 13-20, 195-247; S. Śreniowski, Uwłaszczenie chłopów w Polsce, Warszawa 1956; W. Jakóbczyk, Uwłaszczenie chłopów w Wielkopolsce w XIX w. Warszawa 1951; S. Śreniowski, Studia nad prawem i stosunkami agrarnymi Królestwa Polskiego 1831-1864, Warszawa 1963; K. Groniowski, Realizacja reformy uwłaszczeniowej 1864 roku, Warszawa 1963; K. Groniowski, Kwestia agrarna w Królestwie Polskim 1871-1914, Warszawa 1966; M. Kniat, Dzieje uwłaszczenia włościan w Wielkim Księstwie Poznańskim, t. I, Poznań 1939; t. II, Poznań 1949. 
np. prawo do wypasu bydła na łąkach, prawo do zbierania w lasach drewna na opał;

4) komasacją - tworzeniem gospodarstw o zwartej powierzchni (scalanie gruntów), które polega na zamianie rozproszonych działek należących do jednego właściciela na grunty innych właścicieli, leżące wokół jego działki;

5) parcelacją - podziałem gruntów większych gospodarstw rolnych na mniejsze działki sprzedawane lub przekazywane w użytkowanie.

Oczywiście reformy rolne w dużej mierze były uwarunkowane wydarzeniami politycznymi, takimi jak okres wojen napoleońskich, Wiosna Ludów, powstanie styczniowe. W szczególności w zaborze rosyjskim były próbą oparcia rządów zaborczych na ludności wiejskiej, zgodnie z zasadą divide et impera. Warto także zaznaczyć, że spłata należności pieniężnych (indemnizacja) została rozłożona na szereg lat, a w zaborze rosyjskim (Królestwo Polskie) chłopi płacili rządowi, $\mathrm{w}$ formie podatku, zwrot wypłaconego przez państwo odszkodowania obszarnikowi przez 50 lat, bo aż do 1915 r. ${ }^{6} \mathrm{~W}$ związku z reformami uwłaszczeniowymi oraz zniesieniem systemu poddaństwa chłopów kształtował się w XIX oraz XX wieku, zwłaszcza przed wybuchem pierwszej wojny światowej, socjalistyczny program przebudowy ustroju agrarnego polskiej wsi ${ }^{7}$.

W wyniku reform agrarnych na ziemiach polskich w XIX w. powstały dość zróżnicowane obszary gospodarstw rolnych, bowiem do dziś nietrudno zauważyć granicę między zaborem rosyjskim a pruskim w okolicach Konina czy Kalisza. Duże pola to obszar zaboru pruskiego, tzw. szachownica - zabór rosyjski, a także austriacki. Reformy rolne spowodowały także powstanie stronnictw politycznych (chłopskich), a także emigrację ludności wiejskiej do Ameryki Północnej oraz Południowej, zwłaszcza z obszaru Galicji, gdzie do chwili obecnej znajdują się liczne skupiska Polonii.

\section{REFORMA ROLNA W II RZECZYPOSPOLITEJ}

Problem tzw. głodu ziemi istniał również in statu nascendi państwowości polskiej po I wojnie światowej. Nie był to tylko dylemat występujący na ówczesnych ziemiach polskich, ale istniał również w innych państwach europejskich, zwłaszcza Europy środkowej ${ }^{8}$. Reforma rolna była istotnym zagadnieniem politycznym,

\footnotetext{
${ }^{6}$ K. Grzybowski, Historia Państwa i Prawa Polski, t. IV..., op.cit., s. 106.

7 Zob. F. Tych, Kwestia rolna w programie SDKPiL, [w:] Lenin a kwestia agrarna w kapitalizmie i socjalizmie, koncepcja zbioru i red. H. Chołaj, Warszawa 1967; M. Śliwa, Myśl agrarna socjalistów polskich w XIX i XX wieku, Kraków 1993.

${ }^{8}$ Zob. F. Bujak, O podziale ziemi i reformie rolnej, Warszawa 1920; F. Bujak, Uwagi krytyczne o naszej reformie rolnej, Warszawa-Lublin-Lódź-Poznań-Kraków 1921; Z. Pietkiewicz, Reforma
} 
które porównywano do zmian w prawie wyborczym czy zasad prawa konstytucyjnego ${ }^{9}$. Zwrócił na to uwagę Franciszek Bujak, który w 1918 r. stwierdził, że „reforma rolna jest przebudową podwalin bytu narodowego, która może setki lat będzie trwała i przez cały ten okres czasu będzie na ten byt niezmiernie silnie oddziaływała" ${ }^{\prime \prime}$. Dlatego już w dniu 10 lipca 1919 r. Sejm Ustawodawczy podjął uchwałę w przedmiocie zasad przyszłej reformy rolnej, która miała charakter rezolucji i stanowiła pewien kompromis między stronnictwami politycznymi, które zasiadały w Sejmie. Co istotne uchwała opublikowana została w Dzienniku Urzędowym Głównego Urzędu Ziemskiego Rzeczypospolitej Polskiej oraz jako druk sejmowy ${ }^{11}$.

W związku z tym miała ona charakter programowy, a co za tym idzie nie stanowiła obowiązującego prawa. Ustalono w niej maksimum posiadania ziemi na 60 - 180 ha, a dla b. zaboru pruskiego oraz ziem wschodnich granica ta mogła być podniesiona do $400 \mathrm{ha}$. Ziemia stanowiąca nadwyżkę ponad ustawowe maksimum miała być przymusowo wywłaszczona po cenach ustalonych w przyszłych ustawach. Wywłaszczenia i podziału ziemi miało dokonać państwo. Natomiast lasy generalnie miały przejść na własność państwa. W uchwale explicite stwierdzono, że „ustrój rolny Rzeczypospolitej Polskiej oprzeć się winien przedewszystkiem

rolna na ziemiach narodów odrodzonych, Warszawa 1921; A. Raczyński, Wywłaszczenie na cele reformy rolnej i ustawy kresowej, Lwów-Warszawa 1921, s. 4-37; L.W. Biegeleisen, Reforma rolna głównych państw europejskich, Warszawa 1926, t. I, II; W. Studnicki, Przewroty i reformy agrarne Europy powojennej i Polski, Warszawa 1927; W. Staniewicz, Uwagi o reformie stosunków rolnych w Polsce, Warszawa 1929; A. Ohanowicz, Ustawa o wykonaniu reformy rolnej i inne ustawy rolne, Poznań 1926, s. 91-133; A. Rose, Reformy rolne w Europie Środkowej po wojnie światowej, Warszawa 1925; Z. Ludkiewicz, Ustrój rolny Polski i jego niedomagania, Warszawa 1935; A. Kobylański, Oświetlenia do programu gospodarczego i zmiany ustroju rolnego $w$ Polsce, Kraków 1927; J. Poniatowski, Cele i założenia Reformy Rolnej w 20-leciu Niepodległości, Warszawa 2004; W. Roszkowski, Land Reforms in East Central Europe after World War One, Warszawa 1995; R. Jastrzębski, Zagadnienia prawne reform agrarnych na ziemiach polskich $w$ XX wieku, [w:] Kwestia agrarna. Zagadnienia prawne i ekonomiczne, red. P. Litwiniuk, Warszawa 2016.

${ }^{9}$ Zob. M. Stanulewicz, Reforma rolna jako próba regulacji stosunków agrarnych w Polsce. Koncepcje i próby ich realizacji w latach 1918-1944, [w:] Reformy rolne w Polsce międzywojennej i powojennej. Prawo - realizacja - skutki - problemy reprywatyzacyjne, red. E. Borkowska-Bagieńska, W. Szafrański, Poznań 2008, s. 11 i n.

${ }^{10}$ F. Bujak, O naprawie ustroju rolnego w Polsce, Warszawa-Lublin-Lódź 1918, s. 90.

11 Dz.Urz. Głównego Urzędu Ziemskiego Rzeczypospolitej Polskiej 1920, s. 97-102; Sejm Ustawodawczy (1919-1922), Druk Sejmowy Nr 530, 839. Zob. W.L. Jaworski, Prawa Państwa Polskiego. Zeszyt IV. Prawo agrarne (Od 1 lutego 1918 r. do 1 kwietnia 1920), Kraków 1920, s. 93-102; W. Bitner, S. Janczewski, Ustawa o wykonaniu reformy rolnej, Warszawa 1926, s. 2-27; Reforma rolna. Ustawy i rozporzadzenia rządu, dotyczace ustroju rolnego Rzeczypospolitej Polskiej wydane i wyjaśnieniami zaopatrzone, red. Z. Nagórski, Warszawa 1919; A. Ohanowicz, op.cit., s. 134-154; Cz. Madajczyk, Burżuazyjno-obszarnicza reforma rolna w Polsce 1918-1939, Warszawa 1956, s. $128 \mathrm{in}$. 
na silnych, zdrowych i zdolnych do intensywnej produkcji gospodarstwach włościańskich, opartych na zasadzie prywatnej własności różnego typu i wielkości”"12.

Kolejną regulacją była ustawa z dnia 15 lipca 1920 r. o wykonaniu reformy rolnej ${ }^{13}$, która miała stanowić odpowiednie rozwinięcie uchwały. Wydanie ustawy zbiegło się z sytuacją militarną w wojnie polsko-bolszewickiej. Zwrócił na to uwagę F. Bujak, który stwierdził, że wpływ na to miała „sytuacja Państwa z powodu gwałtownego odwrotu wojsk polskich z pod Kijowa, z nad Dźwiny i Berezyny, oraz znacznego rozluźnienia karności i dezercji. Groźny stan Państwa wymagał, aby nie pominąć żadnego środka, któryby wzmocnił w ludności ducha wierności i wytrwania, a w armji stanowczą wolę zwycięstwa”, co istotne ,zaliczano do tych środków słusznie także i ustawę o reformie rolnej, to zaś zdecydowało o pośpiechu, z jakim doszła do skutku w Komisji, oraz o tem, że przyjęta została w Sejmie jednogłośnie, bez żadnej dyskusji, po krótkiem przemówieniu sprawozdawcy"14.

Podstawowe zasady reformy rolnej dotyczyły:

1) przymusowego wykupu ziemi wielkiej własności, przy pozostawieniu obszaru poniżej pewnego maksimum;

2) częściowej indemnizacji za wywłaszczoną ziemię, wypłacaną obszarnikowi;

3) przywilejów dla żołnierzy, zwłaszcza inwalidów, oraz miejscowych robotników rolnych oraz właścicieli gospodarstw karłowatych;

4) ograniczeń w obciążaniu i alienacji tak powstałych gospodarstw;

5) parcelacji, która miała być dokonywana tylko przez organy państwowe.

Warto dodać, że w porównaniu do uchwały Sejmu Ustawodawczego ustawa nie obejmowała upaństwowienia lasów, które miały pozostać prywatną własnością ${ }^{15}$.

Przeprowadzeniem reformy miała zająć się administracja rolna, która powstała już za Rady Regencyjnej, na czele z Główną Komisją Ziemską ${ }^{16}$. Istotne znaczenie dla późniejszych losów reformy miała wielkość indemnizacji (odszko-

12 Dz.Urz. Głównego Urzędu Ziemskiego Rzeczypospolitej Polskiej 1920, s. 97.

13 Dz.U. z 1920 r. nr 70 poz. 462. Szerzej: F. Bujak, O podziale ziemi..., op.cit., s. 85 i n.; W.L. Jaworski, Prawa Państwa Polskiego. Zeszyt IV A. Prawo agrarne. Uzupetnienie: Reforma rolna, Kraków 1921; J. Nowak, Krzywda chłopska, czyli o tem jak tumaniono chłopów reforma rolna, Warszawa 1924; W. Stankiewicz, Wrzenie rewolucyjne na wsi polskiej w końcu 1918 i w 1919 roku, „Kwartalnik Historyczny” 1955, nr 1.

${ }^{14}$ F. Bujak, Uwagi krytyczne..., op.cit., s. 24.

15 Szerzej: A. Raczyński, Wywtaszczenie..., op.cit., s. 55 i n.; A. Ajnenkiel, Ustawodawstwo agrarne, [w:] Historia Państwa i Prawa Polski 1918-1939, cz. I, red. F. Ryszka, red. ogólna J. Bardach, Warszawa 1962, s. 340 i n.; Cz. Madajczyk, Burżuazyjno-obszarnicza reforma rolna ..., op.cit., s. $155-161$.

16 Zob. dekret Rady Regencyjnej Królestwa Polskiego z 11 października 1918 r. w przedmiocie przepisów tymczasowych o Urzędach Ziemskich (Dz. Praw Królestwa Polskiego nr 11 poz. 22); ustawa z dnia 22 lipca 1919 r. w przedmiocie utworzenia Głównego Urzędu Ziemskiego (Dz. Praw Państwa Polskiego nr 63 poz. 376); ustawa z dnia 6 lipca 1920 r. o organizacji urzędów ziemskich (Dz.U. z 1920 r. nr 70 poz. 461). 
dowania), która wynosiła połowę przeciętnej ceny targowej, płaconej za odpowiednie grunty $\mathrm{w}$ danej okolicy. Po wejściu w życie ustawy z dnia 17 marca 1921 r. Konstytucja Rzeczypospolitej Polskiej ${ }^{17}$ powstał problem zgodności ustawy z 1920 r. o wykonaniu reformy rolnej z art. 99 konstytucji, zgodnie z którym odszkodowanie za przymusowo wykupywaną ziemię powinno wynosić jej wartość rynkową, a także z art. 126, który dotyczył uzgodnienia sprzecznych z nią unormowań z postanowieniami ustawy zasadniczej ${ }^{18}$. Warto także zaznaczyć, że przewidziana $\mathrm{w}$ ustawie procedura wywłaszczeniowa bardzo przedłużała samo postępowanie, a w razie sporu między urzędami ziemskimi a wywłaszczonymi właścicielami sprawa wykupu mogła trwać nawet kilka lat i zakończyć się rozstrzygnięciem Sądu Najwyższego. W związku z tym siódmy Zjazd Prawników i Ekonomistów Polskich, który odbył się w Poznaniu w 1922 r., wyraził pogląd, że „uważa za rzecz niecierpiącą zwłoki uzgodnienie przepisów o reformie rolnej z postanowieniami konstytucji i obowiązujących ustaw cywilnych" 19 .

Po wejściu w życie ustawy z dnia 3 sierpnia 1922 r. o Najwyższym Trybunale Administracyjnym (dalej: NTA), sprawy z zakresu reformy rolnej znalazły się w kognicji tego Trybunału ${ }^{20}$. Przykładem tego jest wyrok NTA z dnia 18 października 1923 r. ${ }^{21}$ oraz wyroki z dnia 14 stycznia 1924 r. w których NTA orzekł, że ustawa o wykonaniu reformy rolnej jest ówcześnie uzgadniania z treścią Konstytucji z dnia 17 marca $1921 \mathrm{r}^{22}$ Związane to było z tzw. paktem lanckorońskim (1923 r.) zawartym między Związkiem Ludowo-Narodowym, Chrześcijańską Demokracją oraz PSL-Piast. Ostatecznie Sejm uchwalił w dniu 28 grudnia 1925 r. ustawę o wykonaniu reformy rolnej ${ }^{23}$. Ustawa nie była już tak radykalna jak po-

17 Dz.U. z 1921 r. nr 44 poz. 267.

18 Zob. A. Raczyński, Wywłaszczenie..., op.cit., s. 95-105; W.L. Jaworski, Państwo praworządne a reforma rolna. Zbiór artykułów i opinji, Kraków 1922, s. 4 i n.; List otwarty Władysława Leopolda Jaworskiego do Ministra Skarbu, dotyczący reformy rolnej, który ukazał się na łamach „Czasu”; opinia Prokuratorii Generalnej (podpisana przez Prezesa Prokuratorii Generalnej Stanisława Bukowieckiego) skierowana do Pana Ministra Skarbu z dnia 23 stycznia 1922 r., zawarte w: Archiwum Akt Nowych, Prokuratoria Generalna RP w Warszawie 1919-1939, sygn. 2347; M. Pietrzak, Państwo prawne w Konstytucji z 17 marca 1921 r., „Czasopismo Prawno-Historyczne” 1987, tom XXXIX, z. 2, s. 112-115.

19 [autor nieznany], Reforma rolna a konstytucja polska, „Ruch Prawniczy i Ekonomiczny” 1924, z. 1, s. 158.

${ }^{20}$ Dz.U. z 1922 r. nr 67 poz. 600.

${ }^{21}$ L. rej. 346/22, „Gazeta Sądowa Warszawska” 1923, nr 45, s. 400-402. Zob. M. Stanulewicz, op.cit., s. $32-34$.

${ }^{22}$ L. Rej. 414/22, 1562/23, „Zbiór Wyroków NTA” 1924 poz. 274. Zob. R. Jastrzębski, Konstytucyjność aktów ustawodawczych w judykaturze II Rzeczypospolitej, „Przegląd Sejmowy” 2010, nr 2, s. 87-88.

${ }^{23}$ Dz.U. z 1926 r. nr 1 poz. 1. Szerzej: W. Grabski, Dwa lata pracy u podstaw państwowości naszej (1924-1925), Warszawa 1927, s. 143-146; W. Bitner, S. Janczewski, op.cit.; A. Ohanowicz, op.cit.; W.L. Jaworski, Reforma rolna, Kraków 1926; H. Stark, E. Stein, Reforma rolna. Wyjaś- 
przednie unormowanie czy wcześniejsza uchwała Sejmu Ustawodawczego. Regulacja została oparta na następujących zasadach, mianowicie:

1) przymusie parcelacyjnym, przy czym poza parcelacją przeprowadzaną przez urzędy państwowe wprowadzona została także tzw. parcelacja prywatna, realizowana przez samego obszarnika albo instytucję prywatną;

2) reforma rolna miała objąć grunty stanowiące własność państwa i instytucji prawa publicznego oraz przekraczające określone maksimum powierzchni, które zasadniczo wynosiło 60 ha - okręgi przemysłowe i podmiejskie, 180 ha pozostałe obszary, poza województwami wschodnimi, w przypadku gospodarstw wyróżniających się intensywnością produkcji maksimum wynosiło od 350 do 700 ha;

3) rocznym kontyngencie parcelacyjnym, określanym co roku przez Radę Ministrów;

4) właściciel sam oznaczał, która część majątku ma zostać przez niego zatrzymana, do wysokości ustawowego maksimum;

5) wielkość indemnizacji stanowił szacunek gruntów oraz nakładów, zmniejszony o wartość obciążających nieruchomość serwitutów; zaś odszkodowanie płatne było częściowo gotówką, a także listami 5\% państwowej renty ziemskiej, która miała być umorzona w okresie do 41 lat;

6) wartość nieruchomości miała odpowiadać rynkowej cenie, przy czym przewidywano pomoc państwa dla nabywców ziemi ${ }^{24}$.

Oczywiście regulacje prawne z zakresu reformy rolnej nie ograniczały się tylko do samej ustawy z grudnia 1925 r., ale dotyczyły m.in. działalności Ministra Reform Rolnych, organizacji urzędów i komisji ziemskich, Państwowego Banku Rolnego, Funduszu Obrotowego Reformy Rolnej, ochrony drobnych dzierżawców, likwidacji serwitutów, scalania gruntów, uporządkowania wspólnot gruntowych $^{25}$ czy likwidacji tzw. stosunków żelarskich na Spiszu i Orawie, które zdaniem Oswalda Balzera uznać należało za stosunek pańszczyźniany ${ }^{26}$. Dlatego po wejściu w życie ustawy z 1925 r. o wykonaniu reformy rolnej Minister Reform Rolnych Witold Staniewicz powołał do życia Komisję Uporządkowania Ustawodawstwa Agrarnego, której przewodniczącym był Władysław Leopold Jawor-

nienia. Ustawodawstwo związowe. Orzecznictwo, Kraków-Warszawa 1939; T. Łebiński, Ustawa o wykonaniu reformy rolnej, Poznań 1937.

${ }^{24}$ Szerzej: A. Ohanowicz, op.cit., s. 155 i n.; T. Brzeski, Walka o reformę rolna, „Ruch Prawniczy, Ekonomiczny i Socjologiczny" 1926, z. 1; A. Ajnenkiel, Ustawodawstwo agrarne, [w:] Historia Państwa i Prawa Polski 1918-1939, cz. I, op.cit., s. 344 i n.; Cz. Madajczyk, Burżuazyjno-obszarnicza reforma rolna..., op.cit., s. 183 i n.

${ }^{25}$ Szerzej: Z. Ludkiewicz, Podręcznik polityki agrarnej, t. I, II, Warszawa 1932; B. Sosnowski, Zbiór przepisów o parcelacji nieruchomości ziemskich wedlug stanu w dniu 1 marca 1938 r., Warszawa 1938.

${ }^{26}$ Zob. M. Hulewicz, Pozostałości ustroju pańszczyźnianego w XX wieku na polskim Spiszu i Orawie, „Roczniki z Dziejów Społecznych i Gospodarczych” 1938, t. VII, s. 124-125. 
ski $^{27}$. Zgodnie z założeniami jej prac ustawa z 1925 r. o wykonaniu reformy rolnej miała charakter przejściowy, a reforma rolna miała być wprowadzona na inne tory $^{28}$. Ostatecznie komisja opracowała Projekt Kodeksu Agrarnego, który ukazał się drukiem w $1928 \mathrm{r}$. W praktyce jednak nadal obowiązywała ustawa o reformie rolnej z 1925 r., przy czym poza ustawą znalazła się parcelacja majątków kościelnych, regulowana przez art. XXIV Konkordatu z 1925 r. ${ }^{29}$, a także obszar Górnego Śląska, w okresie obowiązywania konwencji górnośląskiej (1922 - 1937), wówczas bowiem obowiązywało tam ustawodawstwo niemieckie ${ }^{30}$.

Przeprowadzenie reformy rolnej zostało w dużym stopniu zahamowane w okresie wielkiego kryzysu gospodarczego lat 30., który stanowił poważny cios dla produkcji rolniczej. Oznaczał bowiem w polskiej rzeczywistości drastyczny spadek dochodowości warsztatów rolnych - potencjalnych nabywców parcelowanej ziemi, w tym realny spadek cen nieruchomości rolnych ${ }^{31}$. Warto dodać, że w tym okresie przeprowadzono tzw. akcję oddłużeniową, której podstawę prawną stanowiło rolnicze ustawodawstwo antykryzysowe ${ }^{32}$, a pewne ożywienie akcji parcelacyjnej nastąpiło dopiero w $1936 \mathrm{r}$. W rezultacie przeprowadzonej reformy rolnej w II Rzeczypospolitej, według szacunków, własność chłopska powiększyła się o 13\%, a powierzchnia majątków obszarniczych zmniejszyła się o $16 \%^{33}$. W związku z tym zmiany własnościowe na polskiej wsi nie miały radykalnego charakteru, a wielokrotny Minister Rolnictwa i Reform Rolnych z okresu II Rzeczypospolitej Juliusz Poniatowski, stwierdził, że „reforma rolna w niepodległej Polsce ani się nie stała historycznym aktem przymierza odrodzonego państwa z zaniedbywaną dotychczas najliczniejszą grupą narodu - jak to marzyli sobie społecznicy, ani nie spełniła tak wielkich nadziei - jakie w niej pokładał lud wiejski, ani nie odegrała tak ważnej roli gospodarczej - jaką spełnić mogła", a ,jej niedokończenie, jej powolne sączenie się poprzez dziesięciolecia, jej me-

${ }^{27}$ Zob. W.L. Jaworski, Projekt Kodeksu Agrarnego, Warszawa 1928, s. 1.

${ }^{28}$ Ibidem, s. 7.

${ }^{29}$ Dz.U. z 1925 r. nr 72 poz. 501. Zob. A. Ajnenkiel, Ustawodawstwo agrarne, [w:] Historia Państwa i Prawa Polski 1918-1939, cz. I, op.cit., s. 353-354.

${ }^{30}$ Zgodnie z art. 1 ust.1 pkt 1 ustawy z dnia 7 sierpnia 1937 r. o rozciągnięciu na górnośląską część województwa śląskiego przepisów o wykonaniu reformy rolnej (Dz.U. z 1937 r. nr 60 poz. 471), rozciągnięto moc obowiązującą ustawy z 1925 r. o wykonaniu reformy rolnej.

${ }^{31}$ Zob. Cz. Madajczyk, Burżuazyjno-obszarnicza reforma rolna ..., op.cit., s. 260 i n.; J. Ciepielewski, Polityka agrarna rzadu polskiego w latach 1929-1935, Warszawa 1968; Z. Landau, J. Tomaszewski, Wielki Kryzys 1930-1935. Gospodarka Polski Międzywojennej 1918-1939, t. III, Warszawa 1982, s. 154 i n.

32 Szerzej: R. Jastrzębski, Wplyw sity nabywczej pieniądza na wykonanie zobowiąań prywatno-prawnych w II Rzeczypospolitej, Warszawa 2009, s. 271 i n.

${ }^{33}$ Zob. M. Mieszczankowski, Struktura agrarna Polski międzywojennej, Warszawa 1960, s. 69; W. Staniewicz, Zmiany w strukturze agrarnej Polski, „Ruch Prawniczy, Ekonomiczny i Socjologiczny" 1936, z. 4. 
toda przeważnie uchylająca bezpośrednie zetknięcie z państwem, a skazująca na targ o kupno ziemi od dziedzica, wreszcie jej beztroskliwe i twarde zaniedbanie pomocy finansowej w latach zagospodarowania - pozbawily ją charakteru pamiętnego państwowego aktu" ${ }^{34}$. O przebiegu reformy rolnej w II Rzeczypospolitej zadecydowały przede wszystkim względy finansowe, na które zwrócił uwagę Henryk Gruber. Zaznaczył on, że „reforma rolna mogła być najważniejszą drogą do podniesienia dobrobytu ludności wiejskiej, ale z braku pieniędzy należało przeprowadzić ją na gruncie wielkiej akcji kredytowej", a nieprzeprowadzenie jej w całości wynikało z faktu, iż Polska ,nie umiała zorganizować strony finansowej, nie dysponowała maszynami i materiałem ludzkim dostatecznie zdolnym do natychmiastowego zagospodarowania ziemi otrzymanej z podziału"35.

Wybuch drugiej wojny światowej spowodował zahamowanie realizacji reformy rolnej. Jednak nie sprawił, że ugrupowania polityczne w kraju oraz na emigracji przestały zajmować się opracowaniem nowych zasad przyszłej reformy, jaką planowano przeprowadzić po zakończeniu wojny. Oczywiście programy polityczne dotyczące reformy rolnej miały różny zakres: od zachowawczych do skrajnie radykalnych ${ }^{36}$. Przykładem tych ostatnich jest projekt Polskiej Partii Socjalistycznej oraz Stronnictwa Ludowego, który ukazał się na łamach „Robotnika Polskiego" w 1942 r., wydawanego w Wielkiej Brytanii. Uznano w nim, że „wszelkie pozostałe jeszcze wielkie obszary ziemskie zostaną wywłaszczone. Podstawą ustroju rolnego będzie samodzielny warsztat rolny, stanowiący własność osiadłego na nim rolnika, i obrabiany rękami rodziny. Na części terenów wywłaszczonych winny zostać utworzone samorządowe lub państwowe wzorowe gospodarstwa rolne, stacje doświadczalne, gospodarstwa nasienne i t.p. Wszelka spekulacja ziemią musi być uniemożliwiona. Techniczne, ekonomiczne i organizacyjne braki drobnej gospodarki rolnej usunięte będą przez szeroko rozbudowaną spółdzielczość i równie szeroko rozbudowane szkolnictwo zawodowe"37.

W 1944 r. realne znaczenie miał program polityczny ugrupowań chłopskich, działających przede wszystkim w kraju, oraz Polskiej Partii Robotniczej. Dlatego w Manifeście z grudnia 1943 r. Demokratycznych Organizacji Społeczno-Politycznych i Wojskowych w Polsce uznano, że do zadań Krajowej Rady Narodowej należy m.in. „dążenie do przebudowy ustrojowej Polski w duchu szczerej demokracji, nie tylko politycznej, lecz i gospodarczej, przez wywłaszczenie bez odszkodowania ziemi obszarniczej i oddanie jej chłopom i robotnikom rolnym

34 J. Poniatowski, op.cit., s. 31.

${ }^{35}$ H. Gruber, Wspomnienia i uwagi 1892-1942, Londyn 1968, s. 163-164.

36 Zob. M. Stanulewicz, op.cit., s. 52-62.

${ }^{37}$ Projekt Ustroju Państwa Polskiego. Wniosek P.P.S. i Stronnictwa Ludowego w Radzie Narodowej, „Robotnik Polski” (Wielka Brytania), 15 grudnia 1942 r., nr 24, s. 1. 
(...)"38, a w protokole z pierwszego plenarnego posiedzenia Krajowej Rady Narodowej przedstawiciel grup działaczy ludowych i członków Stronnictwa Ludowego wśród tez programowych mas chłopskich wymienił w punkcie 3: „wywłaszczenie obszarników bez odszkodowania i oddanie ziemi chłopom i robotnikom rolnym" ${ }^{39}$. Oczywiście przeprowadzeniem reformy rolnej, podobnie zresztą jak w okresie dwudziestolecia międzywojennego, najbardziej zainteresowane były ugrupowania wywodzące się z ruchu ludowego ${ }^{40}$, przy czym zasięg reformy rolnej, proponowany w programach poszczególnych stronnictw politycznych, miał często różny charakter ${ }^{41}$. W praktyce jednak partie polityczne, w tym emigracyjne (w Londynie), zdawały sobie sprawę, iż zmiany gospodarczo-społeczne, w szczególności co do struktury agrarnej - zmian własnościowych, w powojennym państwie polskim są nieuniknione. W późniejszej literaturze krajowej po $1945 \mathrm{r}$. zwracano przede wszystkim uwagę na połowiczność i ograniczoność deklaracji programowych rządu emigracyjnego oraz jego ekspozytur krajowych ${ }^{42}$.

\section{REFORMA ROLNA W OKRESIE POLSKI LUDOWEJ}

1. W deklaracji Komitetu Centralnego Polskiej Partii Robotniczej (dalej: KC PPR) z dnia 1 marca 1943 r. pt. O co walczymy?, określono zasady przyszłego programu agrarnego, zapowiadano w nim m.in. przywrócenie ziemi chłopom wywłaszczonym i wysiedlonym przez okupanta, wywłaszczenie bez odszkodowania gospodarstw obszarniczych powyżej 50 hektarów i podział ziemi między małorolnych

38 Protokót pierwszego plenarnego posiedzenia Krajowej Rady Narodowej, Warszawa 31.XII 1943 R./1.I 1944 R., Warszawa 1947, s. V.

39 Ibidem, s. 14. W deklaracji programowej Krajowej Rady Narodowej wśród zadań Rządu Tymczasowego wymieniono m.in. ,wywłaszczenie bez odszkodowania całej ziemi obszarniczej i poniemieckiej w celu przekazania jej chłopom i robotnikom rolnym", ibidem, s. 38.

${ }^{40}$ Zob. Materiaty źródtowe do historii polskiego ruchu ludowego, t. IV: 1939-1945, zebrał J. Nowak, oprac., wstęp i przypisy Z. Mańkowski i J. Nowak, Warszawa 1966, s. 42-46, 202-229, 245-273; K. Przybysz, Chtopi polscy wobec okupacji hitlerowskiej 1939-1945. Zachowania i postawy polityczne na terenach Generalnego Gubernatorstwa, Warszawa 1983, s. 236 i n.

${ }^{41}$ Szerzej: Cz. Madajczyk, Sprawa reformy rolnej w Polsce 1939-1944. Programy - Taktyka, Warszawa 1961, s. 191-206; H. Słabek, O programach reformy rolnej w latach 1939-1944, „Kwartalnik Historyczny” 1962, r. LXIX, z. 2; W. Góra, Ksztattowanie się programu lewicy spotecznej w sprawie przebudowy ustroju rolnego, [w:] Z najnowszych dziejów Polski 1939-1947, red. W. Góra i J. Gołębiewski, Warszawa 1963; W. Góra, Reforma rolna PKWN, Warszawa 1969, s. 16 i n.; W. Michna, A. Szynkarczuk, Rolnictwo w Polsce Ludowej, Warszawa 1964, s. 14-24.

${ }^{42}$ W. Góra, Reforma rolna PKWN, op.cit., s. 41-43; W. Góra, Problemy przebudowy ustroju rolnego w programach wazniejszych stronnictw politycznych $w$ latach okupacji hitlerowskiej, [w:] Problemy wojny i okupacji 1939-1944, red. W. Góra i J. Gołębiowski, Warszawa 1969; H. Słabek, Wieś i rolnictwo, [w:] Polska Ludowa 1944-1950. Przemiany społeczne, red. F. Ryszka, WrocławWarszawa-Kraków-Gdańsk 1974, s. 183-187. 
i robotników rolnych. Podobne postulaty zostały zawarte w deklaracji PPR z listopada 1943 r., w której określono sposób przeprowadzenia reformy rolnej ${ }^{43}$. Następnie w Manifeście Polskiego Komitetu Wyzwolenia Narodowego (dalej: PKWN) z 1944 r., stwierdzono, że ,aby przyspieszyć odbudowę Kraju i zaspokoić odwieczny pęd chłopstwa polskiego do ziemi, Polski Komitet Wyzwolenia Narodowego przystąpi natychmiast do urzeczywistnienia na terenach wyzwolonych szerokiej reformy rolnej. W tym celu utworzony zostanie Fundusz Ziemi, podległy Resortowi Rolnictwa i Reform Rolnych. W skład tego Funduszu wejdą wraz z martwym i żywym inwentarzem i budynkami ziemie niemieckie, ziemie zdrajców narodu oraz ziemie gospodarstw obszarniczych o powierzchni ponad 50 ha, a na terenach, przyłączonych do Rzeszy, w zasadzie o powierzchni ponad 100 ha. Ziemie niemieckie i ziemie zdrajców narodu zostaną skonfiskowane. Ziemie gospodarstw obszarniczych przejęte zostaną przez Fundusz Ziemi bez odszkodowania, zależnego od wielkości gospodarstwa, lecz za zaopatrzeniem dla byłych właścicieli. Ziemianie, mający zasługi patriotyczne $w$ walce $z$ Niemcami, otrzymają wyższe zaopatrzenie. Ziemie skupione przez Fundusz Ziemi, z wyjątkiem przeznaczonych na gospodarstwa wzorowe, rozdzielone zostaną między chłopów małorolnych, średniorolnych, obarczonych licznymi rodzinami, drobnych dzierżawców oraz robotników rolnych. Ziemia rozdzielona przez Fundusz Ziemi za (minimalną) opłatą, stanowić będzie narówni z dawniej posiadaną ziemią własność indywidualną. Fundusz Ziemi będzie tworzył nowe gospodarstwa względnie dopełniał gospodarstwa małorolne, biorąc za podstawę normę 5 ha użytków rolnych średniej jakości dla średniolicznej rodziny. Gospodarstwa, które nie będą mogły otrzymać tej normy na miejscu, będą miały prawo do udziału w przesiedleniu przy pomocy państwa na tereny z wolną ziemią, zwłaszcza na ziemie wywindykowane od Niemiec"44.

Cytowany in extenso passus Manifestu PKWN miał charakter programowy. Warto zaznaczyć, że treść manifestu była uzgadniana z ówczesnymi władzami radzieckim, a Jakub Berman w rozmowie z Teresą Torańską zaznaczył: „wtedy oni [władze radzieckie] nam tłumaczyli, że niezrobienie w porę reformy rolnej okaże się później ciężkim błędem, będzie godzić w państwowe interesy i jeżeli się z nią spóźnicie - mówili - grubo i drogo za to zapłacicie"45. Reforma rolna,

${ }^{43}$ Ksztaltowanie się podstaw programowych Polskiej Partii Robotniczej w latach 1942-1945 (wybór materiatów i dokumentów), Warszawa 1958, s. 140-147. Zob. W. Góra, Reforma rolna PKWN, op.cit., s. 44-46; W. Góra, Kształtowanie się programu lewicy..., op.cit., s. 138-139.

${ }^{44}$ Załącznik do Dz.U. z 1944 r. nr 1, s. 3. Zob. O reformie rolnej, Archiwum Akt Nowych, Ministerstwo Rolnictwa i Reform Rolnych (dalej: AAN, MRiRR), sygn. 1901, karta 6-35; W. Góra, Reforma rolna PKWN, op.cit., s. 64 i n.; A. Burda, Polski Komitet Wyzwolenia Narodowego i Manifest Lipcowy, [w:] Krajowa Rada Narodowa, red. A. Burda, Wrocław-Warszawa-Kraków-Gdańsk 1976, s. 63-79.

45 T. Torańska, Oni, Warszawa 1990, s. 61. 
w tym przejęcie przez państwo lasów oraz nacjonalizacja przemysłu, stanowiła podwaliny zmian polityczno- społeczno- gospodarczych na ziemiach polskich po drugiej wojnie światowej" ${ }^{46}$. Do tego wniosku doszedł już w 1947 r. Konstanty Grzybowski, który stwierdził, że ,te trzy akty prawne - reforma rolna, upaństwowienie lasów, uspołecznienie przemysłu - łączenie z uchwalonym 28 września 1946 planem gospodarki narodowej stworzyły nowy ustrój społeczno- gospodarczy Polski"47.

W związku z tym reforma rolna przeprowadzona w państwie polskim po drugiej wojnie światowej:

1) stanowiła istotny czynnik umocnienia władzy ludowej;

2) była w tym okresie podwaliną tzw. sojuszu robotniczo-chłopskiego;

3) zlikwidowała de facto grupę właścicieli ziemskich, wywłaszczając ich bez dokonania indemnizacji ${ }^{48}$.

Zwrócił na to uwagę Roman Zambrowski w referacie wygłoszonym na plenum KC PPR w lutym 1945 r., stwierdzając, że „,reforma rolna ma u nas w Polsce charakter, zasięg i głębokość rewolucji chłopskiej, rewolucji agrarnej, bo dokonuje dzieła rewolucyjnego, dokonuje likwidacji określonej klasy społecznej, klasy obszarniczej"49. Do podobnych wniosków doszedł Franciszek Ryszka stwierdzając, że ,w wyniku reformy rolnej obszarnictwo jako klasa zniknęło z powierzchni życia ekonomiczno-społecznego i utraciło bezpośrednie polityczne wpływy"50. Natomiast Anna Szemberg w opracowaniu z 1953 r. explicite uznała, że ,wywłaszczenie obszarnictwa i rozdanie ziemi pracującemu chłopstwu było historyczną zasługą reformy rolnej PKWN”, a „przeprowadzenie reformy rolnej

${ }^{46}$ Ustawa z dnia 3 stycznia 1946 r. o przejęciu na własność Państwa podstawowych gałęzi gospodarki narodowej (Dz.U. z 1946 r. nr 3 poz. 17). Zob. A. Kraus, Ustawa o nacjonalizacji przemystu, „Państwo i Prawo” 1946; A. Machnikowska, Prawo wtasności w Polsce w latach 1944-1981. Studium Historycznoprawne, Gdańsk 2010, s. 163 i n.

${ }^{47}$ K. Grzybowski, Ustrój polityczny Polski, [w:] Zarys historyczno-polityczny I-go rządu demokratycznego w Polsce 1944-1946, Warszawa 1947, s. 46.

${ }^{48}$ Zob. Reforma Rolna, Warszawa-Lódź-Lublin 1945; A. Szemberg, Reforma rolna PKWN, Warszawa 1953, s. 54-56; H. Słabek, O niektórych zagadnieniach reformy rolnej PKWN. Na podstawie stenogramu wykładu wygłoszonego na kursie Wydziału Propagandy i Agitacji KC PZPR, Warszawa 1958, s. 3 i n.; W. Góra, PPR $w$ walce o podziat ziemi obszarniczej (1944-1945), Warszawa 1962, s. 103 i n.; J. Paliwoda, Przebudowa ..., op.cit., s. 35 i n.; W. Góra, H. Słabek, Polityka rolna władzy ludowej w latach 1944-1948, [w:] Z dziejów Polski Ludowej, red. W. Góra, J. Gołębiowski, Warszawa 1966, s. 163-171; W. Góra, Polityka rolna PPR w latach 1944-48, [w:] Lenin a kwestia agrarna $w$ kapitalizmie i socjalizmie, op.cit.; W. Góra, Reforma rolna PKWN oraz rola partii robotniczych w jej przeprowadzeniu, [w:] Historia polskiego ruchu robotniczego 1864-1964, t. II: 1939-1964, Warszawa 1967, s. 203-208.

${ }^{49}$ Reforma Rolna PKWN. Materiaty i dokumenty, Warszawa 1959, s. 92. Zob. W walce o sojusz robotniczo-chlopski. Wybór dokumentów i materiatów 1944-1949, Warszawa 1963, s. 50-59.

${ }^{50}$ F. Ryszka, »Sprawa Polska« i sprawy Polaków. Szkice z lat 1944-1946, Warszawa 1966, s. 106. 
było głównym zadaniem społeczno-ekonomicznym pierwszego etapu rewolucji w Polsce - etapu rewolucji burżuazyjno- demokratycznej" ${ }^{51}$. Ponadto zaznaczyła ona, iż ,głęboko rewolucyjny charakter naszej reformy rolnej i jej konsekwentna realizacja sprawiły, że stała się ona jednym z podstawowych czynników umocnienia naszej władzy ludowej" 52 . Warto zaznaczyć, że reforma rolna wynikała ze struktury ówczesnego społeczeństwa polskiego, gdyż, jak zaznaczył Władysław Góra, ,przeprowadzenie radykalnej, plebejskiej reformy rolnej w Polsce, w kraju, w którym chłopi stanowili ponad 2/3 ludności - było główną treścią przeobrażeń rewolucyjno-demokratycznych, miało decydujące znaczenie dla umocnienia sojuszu robotniczo-chłopskiego, dla umocnienia władzy ludowej"s3.

Warto zaznaczyć, że reformy rolne po zakończeniu drugiej wojny światowej objęły swoim zasięgiem ówczesne tzw. kraje demokracji ludowej, czyli: Albanię, Bułgarię, Czechosłowację, Jugosławię, Niemiecką Republikę Demokratyczną, Rumunię, Węgry ${ }^{54}$. Jednak Polska Ludowa była pierwszym europejskim państwem tzw. demokracji ludowej, które rozpoczęło realizację reformy rolnej już w $1944 \mathrm{r}^{55}$, przy czym wykonanie reformy rolnej przebiegało w innych warunkach na tzw. ziemiach dawnych w 1944 r. niż na terenach wyzwolonych w 1945 r. ${ }^{56}$ Ponadto reformy rolne w tych krajach miały stanowić wstęp do przyszłej kolektywizacji rolnictwa, gdyż jak twierdzono, ,pracujące chłopstwo krajów demokracji ludowej śmiało wstępuje na drogę socjalizmu, na drogę przejścia od indywidualnych gospodarstw do kolektywnych gospodarstw socjalistycznych, bowiem kołchozowa droga, droga socjalizmu to jedyna słuszna droga dla pracującego chłopstwa" 57 .

${ }^{51}$ A. Szemberg, Reforma ..., op.cit., s. 5-6.

${ }^{52}$ Ibidem, s. 9.

${ }^{53}$ W. Góra, Reforma rolna PKWN, [w:] Z najnowszych dziejów Polski 1939-1947, op.cit., s. 289.

${ }^{54}$ Szerzej: W. Góra, Niektóre problemy przeobrażeń agrarnych $w$ Polsce i Butgarii $w$ latach 1944-1948 (I) (Studium porównawcze), „Wieś Współczesna” 1969, nr 10; Reformy agrarne w socjalistycznych państwach Europy (1944-1948). Zbiór dokumentów i materiatów, red. W. Góra, Wrocław-Warszawa-Kraków-Gdańsk-Łódź 1987.

${ }_{55}$ Zob. W. Góra, Reforma rolna PKWN, [w:] Z najnowszych dziejów Polski 1939-1947, op.cit., s. $299-301$.

${ }^{56}$ Ibidem, s. 315-323.

57 N.D. Kazancew, Przebudowa rolnictwa w krajach demokracji ludowej, „Państwo i Prawo” 1950, s. 79. Zob. [autor nieznany], Nowe formy rozwoju wsi polskiej, „Państwo i Prawo” 1959, z. 89, s. 219-222; J. Fiema, H. Świątkowski, Problematyka prawna rolnictwa, [w:] Dziesięciolecie Prawa Polski Ludowej 1944-1954. Zbiór Studiów, red. L. Kurowski, Warszawa 1955, s. 258-264; Z. Tomaszewski, Drogi realizacji socjalistycznej przebudowy stosunków agrarnych w Polsce, [w:] Lenin a kwestia agrarna w kapitalizmie i socjalizmie, op.cit.; I. Kostrowicka, Rozwój rolnictwa w latach 1947-1955, [w:] Gospodarka Polski Ludowej 1944-1955, red. J. Kaliński i Z. Landau, Warszawa 1974, s. 290 i n.; T. Torańska, op.cit., s. 111-116. 
Nie podlega analizie, czy wydane przez polską władzę ludową dekrety, realizujące cele określone w Manifeście PKWN, były prawnie dopuszczalne, a co za tym idzie, czy miała ona legitymację prawna do ich wydania ${ }^{58}$. W zasadzie bowiem nadal formalnie obowiązywała Ustawa Konstytucyjna z dnia 23 kwietnia 1935 r. $^{59}$, a także działał rząd w Londynie. Natomiast akty prawne wydawane przez PKWN oparte były na status quo, panującym na obszarze wyzwolonym przez Armię Czerwoną oraz jednostki ludowego wojska polskiego. Warto zaś zaznaczyć, że drugim pytaniem odbytego w dniu 30 czerwca 1946 r. głosowania ludowego było: „czy chcesz utrwalenia w przyszłej Konstytucji ustroju gospodarczego, zaprowadzonego przez reformę rolną i unarodowienie podstawowych gałęzi gospodarki krajowej, z zachowaniem ustawowych uprawnień inicjatywy prywatnej?"60. Oczywiście, jak się powszechnie uznaje, referendum zostało sfałszowane, a o jego rzeczywistych wynikach prawdopodobnie nigdy się nie dowie$m y^{61}$. Warto jednak zaznaczyć, że ówczesne stronnictwa opozycyjne, zwłaszcza podziemia niepodległościowego, były przeciwne przeprowadzanej reformie rolnej. W szczególności Wolność i Niezawisłość (WiN), w którego jednej z odezw w sprawie głosowania w referendum ludowym stwierdzono: „ponieważ reforma rolna nie przyniosła nam oczekiwanych wyników, a baza do stworzenia kołchozów, jak również upaństwowienia podstawowych gałęzi gospodarki krajowej, może spowodować zamknięcie wszystkich: drobnych warsztatów handlowych i przemysłowych i rynków dzielnicowych - w drugiej klatce pisz Nie" ${ }^{" 62}$.

Zwolennikami reformy rolnej byli natomiast przedstawiciele tzw. radykalnych ludowców, w szczególności na łamach „Wici” we wrześniu 1944 r. ukazywały się publikacje aprobujące reformę, uznano w nich m.in., że „reforma rolna rozpoczyna wielkie narodowe przemiany społeczno - gospodarcze, w których my chłopi musimy wziąc czynny udział bo to idzie o nasz los, los pełnoprawnych obywateli a po przez nas o los całego narodu" ${ }^{\prime 3}$. Natomiast na Pierwszym Zjeździe Młodzieży Wiejskiej „Wici” w Lublinie, który odbył się w dniach 27-28 sierpnia 1944 r.

${ }_{58}$ Zob. P.T. Kociubiński, Powojenne przeksztatcenia własnościowe w świetle konstytucji, Warszawa 2013, s. 214 i n.

${ }^{59}$ Dz.U. z 1935 r. nr 30 poz. 227. Zob. R. Jastrzębski, Ciagłość państwa polskiego - publikacja dzienników urzędowych wydanych przez władze Rzeczypospolitej Polskiej na uchodźstwie w latach 1939-1990, „Zeszyty Prawnicze Biura Analiz Sejmowych Kancelarii Sejmu” 2017, z. 2.

${ }^{60}$ Ustawa z dnia 27 kwietnia 1946 r. o głosowaniu ludowym (Dz.U. z 1946 r. nr 15 poz. 104).

${ }^{61}$ Zob. K. Kersten, Narodziny systemu władzy. Polska 1943-1948, Poznań 1990, s. 206 i n.; A. Paczkowski, Referendum z 30 czerwca 1946 r. Próba wstępnego bilansu, [w:] Referendum w Polsce wspótczesnej, red. D. Waniek, M.T. Staszewski, Warszawa 1995.

${ }_{62}$ Odezwa WiN w sprawie głosowania w referendum ludowym, [w:] 1944-1947. W walce o utrwalenie władzy ludowej w Polsce, Warszawa 1967, s. 32-33.

${ }^{63}$ Dekret Polskiego Kom. Wyzwol. Narod. O wprowadzeniu reformy rolnej, „Wici”, Lublin 17 września 1944 r., s. 7. 
explicite stwierdzono, że ,zjazd młodzieży wiejskiej wita z radością zapowiedź natychmiastowego przeprowadzenia reformy rolnej, na którą na próżno od roku 1918 czekały najszersze warstwy obywateli. Zjazd wnosi, aby już w najbliższych tygodniach nastąpiło powszechne wywłaszczenie obszarników bez odszkodowania, a ziemia została oddana chłopom i robotnikom rolnym. Zjazd uważa bowiem, że bez przyspieszenia wykonania reformy rolnej, nie będzie spełniony podstawowy warunek urzeczywistnienia demokracji w Nowej Polsce. Zjazd wzywa wszystkie czynniki państwowe i społeczne, aby w dziele położenia tego fundamentu pod rzeczywistą demokrację w odrodzonym państwie, zmobilizowane zostały i usprawnione wszystkie siły, konieczne do natychmiastowego przeprowadzenia reformy rolnej” "64. Ponadto na łamach „Zielonego Sztandaru”, w publikacji zajmującej się podsumowaniem Zjazdu Stronnictwa Ludowego zaznaczono, że „tak, czy inaczej chłop polski odniósł się do dekretu o reformie rolnej jasno, prosto i zdecydowanie. Własność, rentowność, samowystarczalność - oto, jego zdaniem, gospodarstwo rolne, jakie powstać powinno w Polsce powojennej”, a „do takiego gospodarstwa chłop właściwie dążył zawsze" ${ }^{95}$.

Reforma rolna, a tym samym ustawodawstwo agrarne tego okresu, opierała się przede wszystkim na dekrecie PKWN z dnia 6 września 1944 r. o przeprowadzeniu reformy rolnej ${ }^{66}$, który został wydany na podstawie ustawy Krajowej Rady Narodowej z dnia 15 sierpnia 1944 r. o tymczasowym trybie wydawania dekretów z mocą ustawy ${ }^{67}$. Wydanie dekretu spotkało się jednak z zastrzeżeniami Andrzeja Witosa, który domagał się szerszego omówienia zagadnienia reformy rolnej. Wpływ na dalszy przebieg obrad miała Wanda Wasilewska, jak stwierdził bowiem Władysław Gomułka, „unicestwiła ona wówczas obstrukcję A. Witosa obliczoną na odroczenie uchwalenia tego dekretu. Zrezygnował on z oporu, gdy przypomniała mu niedwu-

64 Ibidem, s. 11 (pkt 6, O Reformie rolnej).

65 Bilans Zjazdu Stronnictwa Ludowego, ,Zielony Sztandar”, Lublin 1 października 1944 r., $\mathrm{Nr}$ 2-3, s. 2. Zob. O przebudowę ustroju rolnego, ,Zielony Sztandar”, Lublin 17 września 1944 r., nr 1.

66 Dz.U. z 1944 r. nr 4 poz. 17. Szerzej: A. Listowski, Reforma rolna, [w:] Zarys historycznopolityczny I-go rządu op.cit.; W. Góra, Reforma rolna PKWN, [w:] Z najnowszych dziejów Polski 1939-1947, op.cit., s. 290-298; W. Michna, A. Szynkarczuk, Rolnictwo..., op.cit., s. 24-35; H. Świątkowski, Prawo rolne, Warszawa 1966, s. 45 i n.; W. Góra, Reforma rolna PKWN, op.cit., s. 71 i n.; J Selwa, A. Stelmachowski, Prawo rolne, Warszawa 1970, s. 56 i n.; N. Kołomejczyk, B. Syzdek, Polska w latach 1944-1949. Zarys Historii Politycznej, Warszawa 1971, s. 46-50, 8385; H. Słabek, Wieś i rolnictwo, op.cit., s. 187-205; H. Słabek, Reforma rolna, [w:] Gospodarka Polski Ludowej 1944-1955, op.cit.; A. Suchoń, M. Kowalczyk, Analiza przepisów dekretu PKWN z 6 września 1944 r. o przeprowadzeniu reformy rolnej wraz z późniejszymi zmianami oraz innych aktów prawnych, na podstawie których nastapiło przejęcie nieruchomości ziemskich i lasów, [w:] Reformy rolne w Polsce międzywojennej i powojennej..., op.cit.; R. Michałowski, Regulacja obrotu państwowymi gruntami rolnymi w świetle przepisów o reformie rolnej i osadnictwie na Ziemiach Odzyskanych, ,Miscellanea Historico-Iuridica” 2012, t. XI.

67 Dz.U. z 1944 r. nr 1 poz. 3. 
znacznie jego pobyt w więzieniu w Komi, skąd go wydobyła i wprowadziła do Zarządu Głównego ZPP”68. Sama zaś W. Wasilewska tak opisała to zdarzenie: „w jakiejś chwili przerwy, kiedy przyniesiono kanapki, ktoś mówił coś o pogodzie, a ja zapytałam Witosa: Ciekawe, jaka o tej porze jest pogoda w Komi? Wówczas Witos usiadł i więcej głosu nie zabrał" ${ }^{6}$. Warto zaznaczyć, że w 1943 r. A. Witos siedział tam w więzieniu z wyrokiem śmierci, czekając na jego wykonanie.

2. Dekret PKWN z dnia 6 września 1944 r. o przeprowadzeniu reformy rolnej w swojej pierwotnej wersji składał się zaledwie z 22 artykułów - co już z góry zakładało, że wykonanie dekretu zależeć będzie w praktyce od organów realizujących reformę. Warto zaznaczyć, że wcześniej bo 15 sierpnia 1944 r. wydany został dekret PKWN o organizacji wojewódzkich i powiatowych urzędów ziemskich ${ }^{70}$, który określił organy administracji rolnej zajmujące się przeprowadzeniem reformy. W związku z tym pierwotnie stanowiły one rodzaj administracji specjalnej niezespolonej $\mathrm{z}$ administracją ogólną. Zmiany nastąpiły w związku $\mathrm{z}$ wejściem w życie dekretu z dnia 12 sierpnia 1946 r. o zespoleniu urzędów ziemskich z władzami administracji ogólnej ${ }^{71}$. Zgodnie z tym dekretem sprawy administracji rolnictwa i reform rolnych włączono do zakresu działania wojewodów i starostów, a do załatwiania związanych $\mathrm{z}$ tym spraw miały zastosowanie określone $\mathrm{w}$ dekrecie przepisy rozporządzenia Prezydenta Rzeczypospolitej z dnia 19 stycznia 1928 r. o organizacji i zakresie działania władz administracji ogólnej ${ }^{72}$.

Zgodnie z art. 1 dekretu o przeprowadzeniu reformy rolnej: „reforma rolna w Polsce jest koniecznością państwową i gospodarczą i będzie zrealizowana przy udziale czynnika społecznego zgodnie z zasadami Manifestu Polskiego Komitetu Wyzwolenia Narodowego. Ustrój rolny w Polsce oparty będzie na silnych, zdrowych i zdolnych do wydatnej produkcji gospodarstwach, stanowiących prywatną własność ich posiadaczy". Przeprowadzenie reformy rolnej miało obejmować: upełnorolnienie istniejących gospodarstw o powierzchni poniżej 5 hektarów użytków rolnych, tworzenie nowych samodzielnych gospodarstw rolnych dla

${ }^{68}$ W. Gomułka, Pamiętniki, t. II, red. A. Werblan, Warszawa 1994, s. 491.

69 T. Żenczykowski, Polska Lubelska 1944, Warszawa 1990, s. 140.

70 Dz.U. z 1944 r. nr 2 poz. 4. Projekt dekretu o organizacji komisji ziemskich oraz uwagi do projektu, zob. AAN, MRiRR, sygn. 284, 3371.

${ }^{71}$ Dz.U. z 1946 r. nr 43 poz. 248. Tekst projektu ustawy z uzasadnieniem oraz uwagami: AAN, MRiRR, sygn. 296. Zob. zarządzenie Ministrów: Rolnictwa i Reform Rolnych, Administracji Publicznej i Ziem Odzyskanych z dnia 24 stycznia 1947 r. w sprawie wykonania dekretu z dnia 12 sierpnia 1946 r. o zespoleniu urzędów ziemskich z władzami administracji ogólnej (Dz.Urz. Ministerstwa Rolnictwa i Reform Rolnych nr 1 poz. 3). Zob. J. Paliwoda, Przebudowa ..., op.cit., s. 27-34.

72 Obwieszczenie Ministra Spraw Wewnętrznych z dnia 25 sierpnia 1936 r. w sprawie ogłoszenia jednolitego tekstu rozporządzenia Prezydenta Rzeczypospolitej o organizacji i zakresie działania władz administracji ogólnej (Dz.U. z 1936 r. nr 80 poz. 555). 
bezrolnych, robotników i pracowników rolnych, w tym drobnych dzierżawców, tworzenie w okolicach miast i ośrodków przemysłowych gospodarstw ogrodniczo-warzywnych, kolonii i ogródków działkowych robotniczych, urzędniczych oraz rzemieślniczych, a także zarezerwowanie terenów dla szkół oraz ośrodków dla podniesienia kultury rolnej, wytwórczości nasiennej, hodowlanej, przemysłu rolnego, poddanych zarządowi państwowemu lub samorządowemu.

$\mathrm{Na}$ cele reformy przechodziły nieruchomości ziemskie o charakterze rolniczym, które stanowiły m.in. własność Skarbu Państwa, własność obywateli Rzeszy Niemieckiej oraz obywateli polskich narodowości niemieckiej, własność osób skazanych prawomocnie za zdradę stanu, za pomoc udzieloną okupantowi ze szkodą dla państwa lub miejscowej ludności, własność albo współwłasność osób fizycznych lub prawnych, jeżeli ich rozmiar łączny przekraczał 100 ha powierzchni ogólnej, bądź 50 hektarów użytków rolnych, przy czym na terenie województw: poznańskiego, pomorskiego i śląskiego jeśli ich rozmiar łączny przekraczał 100 ha powierzchni ogólnej, niezależnie od wielkości użytków rolnych. Zróżnicowanie obszarowe było uzasadnione względami politycznymi, co było konsekwencją uwłaszczenia chłopów w monarchii pruskiej, powstały bowiem wówczas na tym obszarze gospodarstwa rolne średnio albo wielkotowarowe.

Dekret nie dotyczył wspólnot gruntowych, które często ze względu na ich obszar powinny były zostać przejęte na cele reformy rolnej. Wspólnoty gruntowe bowiem z reguły były gospodarowane przez małorolnych chłopów. Natomiast o nieruchomościach rolnych należących do kościoła katolickiego oraz innych wyznań miał zadecydować Sejm Ustawodawczy ${ }^{73}$. Nieruchomości ziemskie przechodziły bez odszkodowania ex lege na własność Skarbu Państwa, na cele określone w dekrecie. W związku z realizacją przebudowy ustroju rolnego utworzony został Państwowy Fundusz Ziemi (dalej: PFZ), którym miał zarządzać kierownik resortu rolnictwa i reform rolnych. PFZ tworzyły m.in. aktywa Funduszu Obrotowego Reformy Rolnej ${ }^{74}$, utworzonego przed drugą wojną światową, nieruchomości przejęte na cele reformy rolnej, dochody z czynności związanych z przebudową ustroju rolnego, dotacje Skarbu Państwa ${ }^{75}$. Obsługa kasowa funduszu miała

${ }^{73}$ Zob. okólnik Ministra Rolnictwa i Reform Rolnych z dnia 28 grudnia 1945 r. w sprawie nieruchomości ziemskich, należących do kościoła katolickiego lub gmin wyznaniowych innych wyznań (Dz.Urz. Ministerstwa Rolnictwa i Reform Rolnych nr 3 poz. 47).

${ }^{74} \mathrm{Na}$ podstawie dekretu z dnia 28 października 1947 r. o obowiązku uiszczenia opłat przez dłużników b. Funduszu Obrotowego Reformy Rolnej (Dz.U. z 1947 r. nr 66 poz. 408) nałożono na dłużników tego funduszu obowiązek uiszczenia opłaty na rzecz Państwowego Funduszu Ziemi. Zob. Z. Dąbrowski, Waloryzacja należności z reformy rolnej, „Przegląd Notarialny” 1948, t. I, s. $453-456$.

75 Zob. AAN, MRiRR, sygn. 457, 458, 3032, 3044, 3062, 3085; także projekt dekretu o Państwowym Funduszu Ziemi: AAN, MRiRR, sygn. 3060, karta 140-145. Szerzej: A. Zieliński, Formy prawne gospodarowania nieruchomościami rolnymi Państwowego Funduszu Ziemi, Poznań 1980. 
odbywać się za pośrednictwem Państwowego Banku Rolnego. Wydatki związane z przeprowadzeniem reformy rolnej, w tym udzielanie pożyczek na urządzenie gospodarstwa oraz inwestycje, były pokrywane z PFZ.

Wywłaszczeni właściciele, w tym współwłaściciele, mieli opuścić w ciągu trzech dni gospodarstwo ${ }^{76}$, a ich majątki były przejmowane $\mathrm{w}$ całości bez pozostawienia tzw. resztówek 50 czy 100 ha. Indemnizacja (odszkodowanie) nie została w ogóle przewidziana w dekrecie, a byli właściciele mogli jedynie otrzymać samodzielne gospodarstwa rolne, na tych samych zasadach, co chłopi, ale w innym powiecie, lub zaopatrzenie miesięczne w wysokości uposażenia urzędnika państwowego VI grupy ${ }^{77}$.

Z utworzonego zapasu ziemi, którym zarządzał PFZ, miano wydzielać działki o powierzchni nieprzekraczającej 5 ha użytków rolnych średniej jakości, a dla gospodarstw ogrodniczo-warzywniczych 2 ha. Ziemia nadawana była odpłatnie, zaś cena jej była ustalona na stosunkowo niskim poziomie. Mianowicie na 15 centnarów metrycznych żyta (około $50 \mathrm{~kg}$ ) za 1 ha ziemi III klasy, co stanowić miało przeciętny roczny urodzaj z danego obszaru ziemi. Na rok 1944/45 przyjęto cenę 400 zł za centnar żyta ${ }^{78}$. Nabywcy ziemi mogli spłacić cenę ziemi w gotówce lub w naturze $10 \%$ ceny kupna. Spłata reszty ceny była rozłożona dla małorolnych na 10 lat, a dla bezrolnych na 20 lat. Bezrolni nadto mogli uzyskać od powiatowego urzędu ziemskiego, na wniosek gminnej komisji reformy rolnej, odroczenie pierwszej wpłaty na okres do trzech lat. Utworzone na podstawie dekretu gospodarstwa nie mogły być w całości lub części dzielone, sprzedawane, wydzierżawiane i zastawiane, bez zgody uzyskiwanej, w wyjątkowych wypadkach, od właściwych władz ziemskich. Parcelacji miały nie podlegać wzorowe gospodarstwa dla podniesienia poziomu gospodarki rolnej, a także część ziemi

\footnotetext{
${ }^{76}$ Zgodnie z nowym brzemieniem art. 7 dekretu [dekret z dnia 17 stycznia 1945 r. w sprawie zmiany dekretu PKWN z dnia 6 września 1944 r. o przeprowadzeniu reformy rolnej (Dz.U. z 1944 r. nr 3 poz. 9)]. Zob. dekret z dnia 12 czerwca 1945 r. o przeniesieniu własności resztówek majątków rozparcelowanych na spółdzielnie Samopomocy Chłopskiej (Dz.U. z 1945 r. nr 27 poz. 162).

${ }^{77}$ Art. 17 dekretu [tekst jednolity: obwieszczenie Ministra Rolnictwa i Reform Rolnych z dnia 18 stycznia 1945 r. w sprawie ogłoszenia jednolitego tekstu dekretu PKWN z dnia 6 września 1944 r. o przeprowadzeniu reformy rolnej (Dz.U. z 1944 r. nr 3 poz. 13)] został uchylony przez art. 127 ust. 4 pkt 1 ustawy z dnia 23 stycznia 1968 r. o powszechnym zaopatrzeniu emerytalnym pracowników i ich rodzin (Dz.U. z 1968 r. nr 3 poz. 6). System uposażeń urzędników państwowych przewidywał 12 grup.

${ }^{78}$ Cenę żyta określał minister rolnictwa (i reform rolnych), na podstawie zarządzeń ogłaszanych w Monitorze Polskim. Zob. zarządzenie Ministra Rolnictwa i Reform Rolnych z dnia 5 stycznia 1949 r. w sprawie ustalenia ceny żyta dla obliczenia należności za ziemię, nabytą z parcelacji (MP Nr A-6 poz. 73); zarządzenie Ministra Rolnictwa z dnia 20 marca 1957 r. w sprawie ceny żyta przy spłatach należności za ziemię nabytą na podstawie przepisów o reformie rolnej i osadnictwie (MP nr 29 poz. 201); zarządzenie Ministra Rolnictwa z dnia 16 sierpnia 1958 r. w sprawie ustalenia ceny żyta przy spłatach w gotówce należności Państwowego Funduszu Ziemi (MP nr 65 poz. 381).
} 
przeznaczona dla szkół rolniczych i powszechnych oraz związana z użytecznością publiczną ${ }^{79}$. Wykaz takich majątków - nie podlegających podziałowi - miało ustalić rozporządzenie kierownika resortu rolnictwa i reform rolnych. Poza tym dekret uprzywilejowywał w nabyciu ziemi m.in. żołnierzy wojska polskiego, inwalidów wojennych czy uczestników walk partyzanckich z Niemcami o Polskę demokratyczną.

Postępowanie w zakresie przeprowadzenia reformy rolnej miało charakter administracyjny, a dla współdziałania z organami państwowymi tworzone były gminne komisje reformy rolnej. Komisje składały się z członków wybranych przez obywateli gminy, a konkretnie przez właścicieli gospodarstw poniżej 5 ha, drobnych dzierżawców, w tym robotników i pracowników rolnych. W związku z tym miały one charakter „klasowy”. Do powiatowych urzędów ziemskich, po objęciu w zarząd państwowy nieruchomości ziemskich, należało przede wszystkim sporządzanie dokładnego spisu nieruchomości oraz ich oszacowanie. Natomiast gminne komisje reformy rolnej miały za zadanie w szczególności przeprowadzenie spisu znajdujących się na ich terenie gospodarstw o powierzchni mniejszej niż 5 ha użytków rolnych oraz sporządzenie wykazu: pracowników, robotników rolnych, w tym drobnych dzierżawców rolnych. Na podstawie tych czynności powiatowy urząd ziemski dokonywał podziału ziemi, obiektów, inwentarza żywego i martwego na rzecz nowoutworzonych gospodarstw. Ostateczna decyzja należała do wojewódzkiego urzędu ziemskiego, przy czym w praktyce wykonanie parcelacji należało do powiatowego urzędu ziemskiego, który wprowadzał nabywców w posiadanie nabytych parcel oraz przenosił na nich tytuł własności. Orzeczenie powiatowego urzędu ziemskiego stanowiło formalnoprawny tytuł nabycia nieruchomości, a także dokonania odpowiednich wpisów w księgach hipotecznych (gruntowych) ${ }^{80}$. Nabywca otrzymywał ziemię w stanie wolnym od

${ }^{79}$ Zob. zarządzenie Ministra Rolnictwa i Reform Rolnych z dnia 6 marca 1945 r. w sprawie wykonania Dekretu z dnia 6.IX 1944 r. o przeprowadzeniu reformy rolnej (Dz.Urz. Ministerstwa Rolnictwa i Reform Rolnych nr 1 poz. 4).

${ }^{80}$ Zob. dekret z dnia 24 sierpnia 1945 r. o wpisywaniu do ksiąg hipotecznych (gruntowych) prawa własności nieruchomości przejętych na cele reformy rolnej (Dz.U. z 1945 r. nr 34 poz. 204); dekret $\mathrm{z}$ dnia 8 sierpnia 1946 r. o wpisywaniu w księgach hipotecznych (gruntowych) prawa własności nieruchomości przejętych na cele reformy rolnej (Dz.U. z 1945 r. nr 39 poz. 233); rozporządzenie Ministra Sprawiedliwości z dnia 10 sierpnia 1946 r. o sposobie oznaczania w księdze hipotecznej (gruntowej) nieruchomości przejętych na cele reformy rolnej i o sposobie składania i przechowywania w sądzie wniosków oraz dokumentów dotyczących takich nieruchomości (Dz.U. z 1946 r. nr 39 poz. 235); dekret z dnia 9 stycznia 1947 r. o wpisywaniu po dniu 31 grudnia 1946 r. w księgach hipotecznych (gruntowych, wieczystych) prawa własności nieruchomości przejętych na cele reformy rolnej (Dz.U. z 1947 r. nr 5 poz. 25); okólnik nr 5 z dnia 30 stycznia 1946 r. w sprawie przeciwdziałania nieobsiewaniu gruntów z parcelacji, otrzymanych przez nowonabywców zasiewów oraz naruszeń art. 13 Dekretu o przeprowadzeniu reformy rolnej (Dz.Urz. Ministerstwa Rolnictwa i Reform Rolnych nr 4 poz. 58); pismo okólne z dnia 28 marca 1946 r. (Nr UR/2-I-1/24), w sprawie wzoru dokumentu nadania ziemi 
wszelkich długów i ciężarów, co de facto oznaczało pierwotne nabycie prawa własności. Natomiast odpowiedzialność Skarbu Państwa za istniejące zadłużenie hipoteczne miała zostać uregulowana odrębnym dekretem. Należy zaznaczyć, że dekret w ogóle nie objął zakresem regulacji majątków ziemskich kościelnych oraz lasów. Ponadto uchylał on moc obowiązującą ustawy z dnia 28 grudnia 1925 r. o wykonaniu reformy rolnej ${ }^{81}$.

3. W dniu 17 stycznia 1945 r. znowelizowano dekret o reformie rolnej ${ }^{82}$. Nowelizacja korespondowała z instrukcją KC PPR z dnia 10 października 1944 r. $\mathrm{w}$ sprawie przeprowadzenia reformy rolnej $\mathrm{w}$ trybie przyspieszonym oraz instrukcją Kierownika Resortu Rolnictwa i Reform Rolnych z dnia 11 października 1944 r. o przyspieszonym trybie wykonania reformy rolnej ${ }^{83}$. Zgodnie z pierwszą instrukcją miały być tworzone brygady agitacyjne, których zadaniem było „rozkołysanie jak najszerszych mas chłopskich wokół realizacji reformy rolnej, złamanie oporu reakcji obszarniczej, rozszerzenie i umocnienie bazy społecznej dla nowego demokratycznego ustroju odradzającej się Polski" ${ }^{\text {84 }}$. Natomiast na podstawie drugiej instrukcji została utworzona instytucja pełnomocników PKWN dla sprawy reformy rolnej oraz dwóch jego zastępców, którzy mieli kontrolować sprawne i szybkie przeprowadzenie podziału ziemi przeznaczonej na cele refor-

(Dz.Urz. Ministerstwa Rolnictwa i Reform Rolnych nr 6 poz. 81); pismo okólne z dnia 10 maja 1946 r. (Nr UR/2.1.1/105), w sprawie ujawnienia w księgach hipotecznych (gruntowych) prawa własności gruntów przejętych na cele reformy rolnej (Dz.Urz. Ministerstwa Rolnictwa i Reform Rolnych nr 6 poz. 84); pismo okólne z dnia 25 maja 1948 r. (Nr UR/2.V.0)/38) w sprawie regulacji prawa własności gospodarstw (Dz.Urz. Ministerstwa Rolnictwa i Reform Rolnych nr 16 poz. 61). Zob. projekty dekretów z uwagami: AAN, MRiRR, sygn. 282, 298; M. Grudziński, Sąy w akcji wpisów do ksiag hipotecznych (gruntowych). Prawa własności nieruchomości przejętych na cele reformy rolnej, „Demokratyczny Przegląd Prawniczy" 1947, nr 5.

${ }^{81}$ Zob. Z. Fenichel, Nieuchylone a jednak nieobowiąujące ustawy, „Państwo i Prawo” 1947, s. $45-48$.

${ }^{82}$ Dekret z dnia 17 stycznia 1945 r. w sprawie zmiany dekretu PKWN z dnia 6 września 1944 r. o przeprowadzeniu reformy rolnej (Dz.U. z 1945 r. nr 3 poz. 9). Zob. W. Góra, Reforma rolna $P K W N$, op.cit., s. 166 i n.

${ }^{83}$ Reforma Rolna PKWN. Materiaty i dokumenty, Warszawa 1959, s. 39-45. Zob. instrukcja Ministra Rolnictwa i Reform Rolnych z 1 marca 1945 r. o wykonaniu reformy rolnej, AAN, MRiRR, sygn. 1900, karta 39-46; pismo okólne z dnia 24 stycznia 1946 r. w sprawie § 28 instrukcji z dnia 1 marca 1945 r. o wykonaniu reformy rolnej (Dz. Urz. Ministerstwa Rolnictwa i Reform Rolnych nr 4 poz. 60); H. Słabek, Polityka agrarna PPR. Geneza, realizacja, konsekwencje, Warszawa 1978, s. 180 i n.; W. Góra, Reforma rolna PKWN, op.cit., s. 115 i n.; Reformy agrarne..., op.cit., s. 144-149; J. Surowiec, Spór o koncepcję ustroju państwowego Polski w okresie Krajowej Rady Narodowej (1944-1946), Wrocław 1982, s. 73-85.

${ }^{84}$ PPR. Rezolucje, odezwy, instrukcje i okólniki Komitetu Centralnego. VIII. 1944-XII.1945. W XV rocznicę Polski Ludowej, Warszawa 1959, s. 71; B. Dymek, Rola PPR w przeprowadzeniu reformy rolnej w województwie warszawskim (1944-1945), około 1963, s. 7. 
my rolnej. Wydawane przez nich zalecenia w zakresie realizacji reformy rolnej były wiążące dla kierowników urzędów ziemskich i ich personelu. Ponadto pełnomocnicy na podstawie instrukcji uzyskali prawo zawieszania w urzędowaniu pracowników urzędów ziemskich, którzy „sabotują lub hamują realizację reformy rolnej”. Dawni właściciele zaś mieli być usuwani z majątku w terminie trzydniowym od chwili jego przejęcia przez administrację państwową oraz nie mogli zamieszkiwać w obrębie gmin, w których znajdował się ich majątek ${ }^{85}$.

Wynika z tego, że ówczesne akty polityczne, wydane przede wszystkim przez PPR, wyprzedzały zmiany legislacyjne ${ }^{86}$, które były niejako sankcjonowane w wydawanych później aktach prawnych. Zwrócił na to uwagę Władysław Gomułka, który stwierdził, że ,istota zwrotu w realizacji dekretu o reformie rolnej wyraziła się w porzuceniu koncepcji legalistycznej na rzecz uruchomienia masowych działań przy pomocy partii i administracji PKWN w celu szybkiego przeprowadzenia parcelacji”"87. Celowi temu służyła także represyjna polityka wobec byłych właścicieli majątków ziemskich oraz odwołanie Andrzeja Witosa ze stanowiska kierownika resortu rolnictwa pod zarzutem niedoceniania roli organów społecznych w wykonywaniu reformy rolnej oraz wprowadzeniu wrogów reformy do urzędów ziemskich, w tym na stanowiska administratorów poobszarniczych majątków ${ }^{88}$.

W związku z tym, w znowelizowanym dekrecie z dnia 17 stycznia 1945 r., zmiany dotyczyły dostosowania regulacji do potrzeb praktyki, w tym m.in. zamieszczenia w dekrecie delegowanych przez ministra rolnictwa i reform rolnych pełnomocników do spraw reformy rolnej oraz aparatu społecznego w postaci folwarcznych komitetów podziału ziemi, działających obok istniejących gminnych komisji reformy rolnej, a także rozszerzono krąg osób uprawnionych o chłopów średniorolnych, w tym pominięto unormowania o działkach robotniczych i rze-

${ }^{85}$ Zob. Reformy agrarne..., op.cit., s. 145-146.

${ }^{86}$ Zob. okólnik KC PPR z 26 września 1944 r. o zadaniach komitetów folwarcznych w realizowaniu reformy rolnej; instrukcja KC PPR z dnia 28 września 1944 r. o zadaniach organizacji partyjnych w przeprowadzeniu prac przygotowawczych dla podziału ziemi obszarniczej; odezwa KC PPR z dnia 3 października 1944 r. pt. Wszyscy do pracy przy realizacji reformy rolnej; okólnik KC PPR z dnia 25 października 1944 r. w sprawie nadsyłania sprawozdań o rozparcelowanych folwarkach; instrukcja KC PPR z dnia 25 października 1944 r. w sprawie zadań organizacji partyjnych w walce z wypaczeniami reformy rolnej; projekt uchwały z dnia 7 lutego 1945 r. rozszerzonego plenum KC PPR o zadaniach partii na wsi; instrukcja KC PPR z dnia 21 lutego 1945 r. w sprawie trybu przeprowadzenia podziału majątków obszarniczych; rezolucja I Zjazdu PPR z dnia 12 grudnia 1945 r. w sprawie pracy partii na wsi; deklaracja stronnictw politycznych z dnia 15 października 1944 r. w sprawie reformy rolnej, zawarte w: PPR. Rezolucje, odezwy, instrukcje..., op.cit., s. 3946, 63-69, 74-75, 81-82, 95-103, 217-223, 263-265; W walce o sojusz robotniczo-chtopski. Wybór dokumentów i materiatów 1944-1949, Warszawa 1963, s. 32-63.

87 W. Gomułka, Pamiętniki, t. II, op.cit., s. 474.

${ }^{88}$ Ibidem, s. 472-474. Zob. T. Żenczykowski, op.cit., s. 142-144; W. Góra, Reforma rolna PKWN, [w:] Z najnowszych dziejów Polski 1939-1947, op.cit., s. 304-311. 
mieślniczych. Ponadto zamieszczono w dekrecie postanowienie, że dawni właściciele (obszarnicy) mają w ciągu trzech dni opuścić wywłaszczony na cele reformy rolnej majątek oraz powinni znaleźć się poza obrębem powiatu ${ }^{89}$. W związku z tym w postanowieniach zarządzenia komendanta Milicji Obywatelskiej (dalej: MO) na województwo warszawskie z dnia 18 sierpnia 1945 r., stwierdzono, że należy „natychmiast wprowadzić chłopów mających akt nadania ponownie w posiadanie działek, z których ich wywłaszczono. Obszarników i ich rządców i ekonomów zgodnie z dekretem usunąc poza powiat". Co interesujące zarządzenie komendanta MO spotkało się z reakcją ówczesnego Ministra Rolnictwa i Reform Rolnych Stanisława Mikołajczyka, który w piśmie z dnia 5 września 1945 r., uznał takie działania za wkraczanie w kompetencje jego resortu, a w praktyce $\mathrm{w}$ atrybucje urzędów ziemskich ${ }^{90}$.

Tekst jednolity dekretu ukazał się jako załącznik do obwieszczenia Ministra Rolnictwa i Reform Rolnych z dnia 18 stycznia 1945 r. ${ }^{91}$ Następnie ukazało się rozporządzenie Ministra Rolnictwa i Reform Rolnych z dnia 1 marca 1945 r. w sprawie wykonania dekretu PKWN z dnia 6 września 1944 r. o przeprowadzeniu reformy rolnej ${ }^{92}$. Rozporządzenie określiło szczegółowo m.in. tryb prze-

${ }^{89}$ Dekret z dnia 17 stycznia 1945 r. w sprawie zmiany dekretu PKWN z dnia 6 września 1944 r. o przeprowadzeniu reformy rolnej (Dz.U. z 1945 r. nr 3 poz. 9). Art. 1 pkt 11 dekretu, wprowadził nowe brzmienie art. 7 dekretu o przeprowadzeniu reformy rolnej, zgodnie z którym delegowani przez Ministra Rolnictwa i Reform Rolnych pełnomocnicy m.in. usuwali dotychczasowych właścicieli w terminie 3-dniowym. Natomiast art. 1 pkt 23 dekretu, wprowadził zmianę w art. 19 ust. 1 dekretu o przeprowadzeniu reformy rolnej, zgodnie z którą sformułowanie: „poza obrębem wywłaszczonego majątku”, zastąpiono sformułowaniem: „poza obrębem powiatu, w którym znajduje się wywłaszczony majątek", co w praktyce oznaczało możliwość nabywania przez wywłaszczonych właścicieli lub współwłaścicieli nieruchomości ziemskich samodzielnych gospodarstw rolnych na podstawie dekretu o reformie rolnej. W tekście jednolitym dekretu [obwieszczenie Ministra Rolnictwa i Reform Rolnych z dnia 18 stycznia 1945 r. (Dz.U. nr 3 poz. 13)] zmieniono numerację artykułów, a dawny art. 19 odpowiadał w tekście jednolitym art. 17. Ponadto instrukcja Ministra Rolnictwa i Reform Rolnych z dnia 1 marca 1945 r. o wykonaniu reformy rolnej (Dz.Urz. Ministerstwa Rolnictwa i Reform Rolnych nr 1 poz. 3) w §12 określała, że organy przejmujące polecą właścicielom majątków przejętych opuszczenie majątku do dni trzech.

${ }^{90}$ Zob. H. Słabek, Polityka agrarna PPR. Geneza, realizacja, konsekwencje, Warszawa 1978, s. $227-228$.

${ }_{91}$ Obwieszczenie Ministra Rolnictwa i Reform Rolnych z dnia 18 stycznia 1945 r. w sprawie ogłoszenia jednolitego tekstu dekretu PKWN z dnia 6 września 1944 r. o przeprowadzeniu reformy rolnej (Dz.U. z 1945 r. nr 3 poz. 13), także: Dz.Urz. Ministerstwa Rolnictwa i Reform Rolnych 1945 r. nr 1. Zob. AAN, Ministerstwo Sprawiedliwości (dalej: MS), sygn. 4162; S. Gołębiewski, Polityka agrarna doby obecnej w świetle wydanych dekretów, „Państwo i Prawo” 1946, z. 5-6; W. Bendetson, Przegląd rozwoju prawodawstwa w zakresie gospodarki rolnej, „Przegląd Ustawodawstwa Gospodarczego" 1956, nr 5, 6; W. Pawlak, Z zagadnień prawnych reformy rolnej w Polsce Ludowej, „Ruch Prawniczy, Ekonomiczny i Socjologiczny” 1958, z. 2.

92 Dz.U. z 1944 r. nr 10 poz. 51. Zmiany: rozporządzenie Ministra Rolnictwa i Reform Rolnych z dnia 8 lipca 1946 r. o zmianie rozporządzenia Ministra Rolnictwa i Reform Rolnych z dnia 
prowadzenia reformy rolnej, kompetencje poszczególnych organów, w tym także zawarte w nim zostały legalne definicje: gospodarstwa karłowatego, użytków rolnych czy osób bezrolnych.

Wydanie tych regulacji prawnych, czyli tzw. zwrot październikowy w realizacji reformy rolnej, korespondowało z wcześniejszą rozmową, jaką odbył Bolesław Bierut z Józefem W. Stalinem w Moskwie. Miała ona miejsce po kolacji 29 września 1944 r. Zgodnie z relacją W. Gomułki: „właśnie pod koniec tej kolacji, kiedy jej uczestnicy po wypiciu szampana z rogów baranich powstali od stołu i rozeszli się w trzech grupach do różnych miejsc biesiadnej sali, Stalin i Mołotow przeprowadzili z Bierutem ów »〈rugatelnyj razgawor «, którego treść zrelacjonował nam Bierut na posiedzeniu biura zaraz po powrocie do Lublina. Brutalne zwymyślanie Bieruta za metody realizowania dekretu o reformie rolnej i za stosunek do wywłaszczonych obszarników odnosiło się faktycznie do całego kierownictwa partii. Musieliśmy więc dokonać gwałtownego zwrotu na tym odcinku działalności partii i PKWN. Ze zrozumiałych względów prawdziwe przyczyny tego zwrotu nie mogły być ujawnione. Znało je tylko wąskie grono ludzi z centralnego kierownictwa partii" ${ }^{\prime 9}$.

W celu przeprowadzenia oraz zabezpieczenia wykonania reformy rolnej zostały wydane inne akty prawne takie jak: dekret PKWN z dnia 7 października 1944 r. o mobilizacji sił mierniczych ${ }^{94}$ do wykonania dekretu o reformie rolnej czy dekret z 30 października 1944 r. o ochronie Państwa ${ }^{95}$, który w art. 2 przewidywał

\footnotetext{
1 marca 1945 r. w sprawie wykonania dekretu z dnia 6 września 1944 r. o przeprowadzeniu reformy rolnej (Dz.U. z 1946 r. nr 34 poz. 215); rozporządzenie Ministra Rolnictwa i Reform Rolnych z dnia 20 listopada 1947 r. o zmianie rozporządzenia Ministra Rolnictwa i Reform Rolnych z dnia 1 marca 1945 r. w sprawie wykonania dekretu z dnia 6 września 1944 r. o przeprowadzeniu reformy rolnej (Dz.U. z 1947 r. nr 72 poz. 456). Zob. przebieg prac nad zmianami dekretu o przeprowadzeniu reformy rolnej oraz rozporządzenia w sprawie wykonania dekretu o przeprowadzeniu reformy rolnej: AAN, MRiRR, sygn. 308, 329, 339, 1900. Także: dekret z dnia 13 września 1946 r. o organizacji komisyj ziemskich (Dz.U. z 1946 r. nr 61 poz. 340); instrukcja Ministra Rolnictwa i Reform Rolnych z dnia 12 grudnia $1946 \mathrm{r}$. w sprawie ustalania ceny sprzedażnej nieruchomości ziemskich i ich przynależności dla nabywców z mocy dekretu z dnia 6 września 1944 r. o przeprowadzeniu reformy rolnej (Dz.U.R.P. nr 3 poz. 13 za 1945 r.), (Dz.Urz. Ministerstwa Rolnictwa i Reform Rolnych z 1947 r. nr 1 poz. 7); pismo okólne z dnia 27 stycznia 1947 r. (nr UR/2.I.1/187) w sprawie stosowania § 44 rozporządzenia Ministra Rolnictwa i Reform Rolnych z dnia 01.03.1945 r. o wykonaniu reformy rolnej (Dz.Urz. Ministerstwa Rolnictwa i Reform Rolnych nr 2 poz. 19); pismo okólne z dnia 5 lutego 1947 r. (nr UR/2.I.1/188) w sprawie Komisyj Ziemskich (Dz.Urz. Ministerstwa Rolnictwa i Reform Rolnych nr 2 poz. 21).

93 W. Gomułka, Pamiętniki, t. II, op.cit., s. 471. Zob. Protokół z posiedzenia KC dnia 9 października 1944 r., [w:] Protokoły z posiedzeń Biura Politycznego KC PPR 1944-1945. Dokumenty $z$ dziejów PRL, z. 2, oprac. A. Kochański, Warszawa 1992, s. 16-29.

${ }_{94}$ Dz.U. z 1944 r. nr 7 poz. 31.

${ }^{5}$ Dz.U. z 1944 r. nr 10 poz. 50. Także zob. art. 20 dekretu z dnia 13 czerwca 1946 r. o przestępstwach szczególnie niebezpiecznych w okresie odbudowy Państwa (Dz.U. z 1946 r. nr 30, poz. 192).
} 
karę więzienia lub karę śmierci za udaremnienie lub utrudnienie wprowadzenia w życie reformy rolnej, albo nawoływanie do czynów skierowanych przeciw wykonaniu lub publiczne pochwalanie takich czynów. Ponadto dekret z dnia 28 listopada 1945 r. o przejęciu niektórych nieruchomości ziemskich na cele reformy rolnej i osadnictwa ${ }^{96}$ wymienił nieruchomości ziemskie „niepodpadające pod działanie dekretu z dnia 6 września 1944 r. o przeprowadzeniu reformy rolnej", które jednak mogły być przejęte na cele reformy rolnej i osadnictwa. Zaliczono do nich nieruchomości ziemskie m.in. pozostałe po osobach przesiedlających się do Związku Socjalistycznych Republik Rad; w związku z wojną lub okupacją przeznaczone na specjalne cele, np. poligony, lotniska, zalesienie, drogi, jeśli utrzymanie tego rodzaju użytkowania nie leżało w interesie państwa polskiego; przejęte za zgodą właściciela oraz wszelkie nieruchomości ziemskie, które w toku przeprowadzania reformy rolnej faktycznie zostały rozparcelowane do 1 sierpnia 1945 r. Ponadto w związku z reformą rolną wyłączano spod parcelacji m.in. grunty na regulację rzek czy przydzielano grunty pracownikom i robotnikom zatrudnionym w gospodarstwach leśnych oraz przemyśle leśnym ${ }^{97}$.

Kluczową rolę w przebiegu reformy rolnej odgrywał tryb administracyjny. Strony oraz osoby zainteresowane miały prawo odwołania się od decyzji powiatowego urzędu ziemskiego do wojewódzkiego urzędu ziemskiego, który po zasięgnięciu opinii wojewódzkiego pełnomocnika dla spraw reformy rolnej wydawał ostateczną decyzję w sprawie operatu parcelacyjnego. Natomiast orzekanie w sprawach, czy dana nieruchomość podlegała działaniu dekretu o reformie rolnej należało w I instancji do kompetencji wojewódzkich urzędów ziemskich, od których decyzji służyło stronom prawo odwołania do ministra rolnictwa i reform rolnych. Decyzje nie mogły być zaskarżone ani do sądu powszechnego, ani administracyjnego $0^{98}$.

Szerzej: M. Kowalczyk, Przestepstwa przeciwko reformie rolnej, [w:] Reformy rolne w Polsce międzywojennej i powojennej..., op.cit.

${ }_{96}$ Dz.U. z 1945 r. nr 57 poz. 321.

${ }^{97}$ Zob. pismo okólne z dnia 23 stycznia 1946 r. w sprawie art. 15 Dekretu P.K.W.N. z dn. 6.IX.1944 r. o przeprowadzeniu reformy rolnej (Dz.Urz. Ministerstwa Rolnictwa i Reform Rolnych nr 4 poz. 59); okólnik nr 4 z dnia 28 stycznia 1946 r. w sprawie przydziału gruntów z reformy rolnej na cele regulacji rzek (Dz.Urz. Ministerstwa Rolnictwa i Reform Rolnych nr 4 poz. 57); pismo okólne z dnia 31 marca 1946 r. (nr UR/2-I-3/7) w sprawie przydziału gruntów z reformy rolnej na cele regulacji rzek (Dz.Urz. Ministerstwa Rolnictwa i Reform Rolnych nr 6 poz. 82); pismo okólne z dnia 8 stycznia 1947 r. (nr UR/2.I.8/76) w sprawie pkt 3 lit. „d” „Tez” rozgraniczenia kompetencji Ministerstwa Rolnictwa i Reform Rolnych i Ministerstwa Leśnictwa (Dz.Urz. Ministerstwa Rolnictwa i Reform Rolnych nr 2 poz. 18); pismo okólne z dnia 6 lutego 1947 r. (nr UR/2.I.8/76) w sprawie wykonania Tez w przedmiocie rozgraniczenia kompetencji Ministerstwa Rolnictwa i Reform Rolnych i Ministerstwa Leśnictwa (Dz.Urz. Ministerstwa Rolnictwa i Reform Rolnych nr 5 poz. 55).

98 Zob. akta spraw, wnioski, pisma, odwołania, sprawozdania, korespondencja, opinie, orzeczenia: AAN, MRiRR, sygn. 420, 426, 1516-1521, 1724-1726, 1848, 1890-1895, 2704, 2708, 
W związku z tym Minister Sprawiedliwości wydał 7 sierpnia 1945 r. okólnik Nr 41/45, dotyczący powództw wytaczanych przez właścicieli nieruchomości ziemskich, którzy po uzyskaniu orzeczenia właściwych władz ziemskich, że nieruchomość ich nie podlegała reformie rolnej, domagali się zwrotu ziemi od nabywców, którzy otrzymali dokument nadania ${ }^{99}$. Zgodnie z nim „,ałą akcję reformy rolnej przeprowadzają władze i urzędy ziemskie $\mathrm{w}$ administracyjnym trybie postępowania”, a „w całej akcji reformy rolnej istnieją dwa stosunki o charakterze publiczno-prawnym: między dotychczasowym właścicielem nieruchomości ziemskiej a Państwem i między Państwem a nowonabywcą; nie ma natomiast węzła prawnego, łączącego pierwotnego właściciela nieruchomości z nowonabywcą". W konsekwencji uznawano, że „brak jest podstawy do wytaczania powództwa przeciw nowonabywcom, skoro ci ostatni nie od niego, lecz od władz państwowych otrzymali ziemię. Ponieważ ponadto chodzi, jak już zaznaczono, o stosunek publiczno-prawny, przeto droga sądowa z mocy art. 2 k.p.c. nie jest dopuszczalna"100.

Dlatego Henryk Świątkowski explicite stwierdził, że ,dekret wykluczył jakikolwiek stosunek prawny między byłym właścicielem ziemskim a chłopem, ustanowił natomiast stosunek publiczno-prawny między chłopem a Państwem (inaczej przed wojną za rządów sanacyjnych - przy parcelacji prywatnej, opartej na umowie kupna-sprzedaży)"101. Sądy powszechne stosowały generalnie regułę niedopuszczalności drogi sądowej w sprawach z zakresu reformy rolnej. Wynikało to przede wszystkim z judykatury Sądu Najwyższego, w której przyjęto zasadę ,nieingerowania oraz niepodważania przez sądy decyzji władz administracyjnych, realizujących przebudowę ustroju rolnego w naszym kraju"102. Dlatego, zgodnie z orzecznictwem Sądu Najwyższego, nabywca nieruchomości ziemskiej, przejętej na cele reformy rolnej, otrzymywał ją w stanie wolnym od wszelkich długów i ciężarów, a przejście majątków ziemskich na własność Skarbu Państwa w drodze reformy rolnej miało charakter nabycia pierwotnego, czyli bez następstwa prawnego, a więc bez obciążeń i zobowiązań ${ }^{103}$.

2718, 2759, 2760. W ten sam sposób rozstrzygnięto tryb odwoławczy w przypadku nacjonalizacji lasów, zob. AAN, Ministerstwo Leśnictwa, sygn. 816-824.

99 Dz.Urz. Ministerstwa Sprawiedliwości z dnia 6 marca 1946 r. nr 1, s. 6-7; Zob. Droga sądowa w sporach na tle reformy rolnej, „Demokratyczny Przegląd Prawniczy” 1945, nr 1, s. 44; St.Ch., Reforma rolna. Wykonanie aktów nadania w trybie egzekucji administracyjnej, „Gazeta Administracji" 1948, nr 6-7, s. 360-361.

${ }^{100}$ Ibidem.

${ }^{101}$ H. Świątkowski, Wyktadnia prawno-społeczna (Uwagi na tle okólnika w sprawie reformy rolnej), „Demokratyczny Przegląd Prawniczy” 1945, nr 1, s. 21.

102 Zob. J. Majorowicz, Przebudowa ustroju rolnego PRL. W orzecznictwie Sądu Najwyższego, Warszawa 1966, s. 4.

${ }^{103}$ Zob. orzeczenia SN z: 13 października 1951 r. C 427/51, „Orzecznictwo Sądu Najwyższego. Izba Cywilna i Karna” 1953, poz. 1; 21 lutego 1957 r. 1 CR 938/56, „Orzecznictwo Sądów 
Warto zaznaczyć, że po drugiej wojnie światowej nie „reaktywowano” Najwyższego Trybunału Administracyjnego, mimo że Ustawa Konstytucyjna z dnia 19 lutego 1947 r. o ustroju i zakresie działania najwyższych organów Rzeczypospolitej Polskiej ${ }^{104}$, przewidywała w art. 26 powołanie osobną ustawą trybu i zakresu działania organów właściwych do orzekania o legalności aktów administracyjnych w zakresie administracji publicznej ${ }^{105}$. Taki sąd administracyjny - Naczelny Sąd Administracyjny ${ }^{106}$ - powstał dopiero w latach 80 . Natomiast w okresie reformy rolnej postępowanie przed organami administracji regulowało rozporządzenie Prezydenta Rzeczypospolitej z dnia 22 marca 1928 r. o postępowaniu administracyjnem ${ }^{107}$.

4. W inny sposób przebiegała reforma rolna na tzw. Ziemiach Odzyskanych. Związana była ona bowiem z osadnictwem repatriacyjnym, wojskowym oraz z terenów Polski Centralnej ${ }^{108}$. Warto podkreślić, że dopiero konferencja poczdamska przesądziła formalnie o statusie ziem zachodnich, a co za tym idzie

Polskich i Komisji Arbitrażowych” 1959, poz. 1; 25 kwietnia 1961 r. 4 CR 88/61, „Orzecznictwo Sądów Polskich i Komisji Arbitrażowych” 1963, poz. 2 z glosą A. Ohanowicza. Szerzej: J. Majorowicz, op.cit., s. 5 i n.; J. Paliwoda, Rola aktu administracyjnego w kształtowaniu stosunków własnościowych w rolnictwie, Warszawa 1965, s. 54 i n.

104 Dz.U. z 1947 r. nr 18 poz. 71. Zob. Małe Konstytucje. Ustawy zasadnicze okresów przejściowych 1919 - 1947 - 1992, red. R. Jastrzębski, M. Zubik, Warszawa 2014, s. 56-96.

105 Zob. E. Modliński, Istota i problemy sadownictwa administracyjnego, „Państwo i Prawo” 1946, z. 7; W. Klonowiecki, Odbudowa sadownictwa administracyjnego, „Gazeta Administracji” 1946, nr 4-6; J.S. Langrod, Sprawa reaktywacji sadownictwa administracyjnego, „Gazeta Administracji” 1946, nr 10-11; W. Dawidowicz, W sprawie sądownictwa administracyjnego, „Państwo i Prawo" 1956, z. 12; R. Jastrzębski, Trybunat Kompetencyjny. Kolegium Kompetencyjne. Geneza. Działalność. Wspótczesność, Warszawa 2014, s. 151 i n.

106 Ustawa z dnia 31 stycznia 1980 r. o Naczelnym Sądzie Administracyjnym oraz o zmianie ustawy - Kodeks postępowania administracyjnego (Dz.U. z 1980 r. nr 4 poz. 8).

107 Dz.U. z 1928 r. nr 36 poz. 341 ze zm. Zob. J. Litwin, Postępowanie administracyjne. Postępowanie karno-administracyjne. Postępowanie przymusowe w administracji. Objaśnione orzecznictwem sądów najwyższych i okólnikami ministerialnymi, Łódź 1948; uchwała składu siedmiu sędziów z dnia 13 października 1951 r. (C. 427/51), [w:] Orzecznictwo Sądu Najwyższego w składach powiększonych. Zbiór wytycznych i uchwat Zgromadzenia Ogólnego Całej Izby i składu siedmiu Sędziów Sądu Najwyższego w sprawach cywilnych za lata 1945-1959, zebrali i oprac.W. Święcicki, K. Piasecki, Warszawa 1961, poz. 68.

108 Szerzej: W. Góra, H. Słabek, Przebudowa ustroju rolnego w Polsce w latach 1946-1949, [w:] Polska Ludowa. IX Powszechny Zjazd Historyków Polskich w Warszawie 13-15 września 1963. Referaty i dyskusja, Warszawa 1964; W. Michna, A. Szynkarczuk, Rolnictwo..., op.cit., s. 36-38; H. Słabek, Polityka agrarna PPR. Geneza, realizacja, konsekwencje, Warszawa 1978, s. 358 i n.; W. Markiewicz, Zasiedlenie i zagospodarowanie ziem zachodnich, [w:] Z dziejów Polski Ludowej, op.cit.; W. Góra, Reforma rolna PKWN, op.cit., s. 226 i n.; W. Góra, H. Słabek, Polityka rolna władzy ludowej w latach 1944-1948..., op.cit., s. 171-177; H. Słabek, Wieś i rolnictwo..., op.cit., s. 207-214. 
dopiero 13 listopada 1945 r. został wydany dekret o zarządzie Ziem Odzyskanych $^{109}$, na które rozciągnięto zasadniczo ustawodawstwo obowiązujące na obszarze Sądu Okręgowego w Poznaniu. W związku z tym teoretycznie miały zastosowanie regulacje PKWN o reformie rolnej, przy czym w praktyce nie były one wykonywane ${ }^{110}$. Dlatego 6 września 1946 r. został wydany dekret o ustroju rolnym i osadnictwie na obszarze Ziem Odzyskanych i byłego Wolnego Miasta Gdańska" ${ }^{11}$. Dekret miał stanowić lex specialis w stosunku do dekretu o przeprowadzeniu reformy rolnej. W praktyce jednak dotyczyło to przede wszystkim określenia górnej granicy wielkości obszaru gospodarstwa rolnego. Cechą podstawową było to, iż zapas ziemi tworzył głównie areał dawnych gospodarstw niemieckich. Także wiązało się z tym ustawodawstwo, dotyczące przede wszystkim majątków poniemieckich, które początkowo było dość zmienne, a ostatecznie zagadnienie to regulował dekret z dnia 8 marca 1946 r. o majątkach opuszczonych i poniemieckich ${ }^{112}$, który był uzupełniany regulacjami prawnymi

109 Dz.U. z 1945 r. nr 51 poz. 295. Zob. J. Litwin, Recepcja prawa polskiego na Ziemiach Odzyskanych, „Państwo i Prawo” 1946, z. 1; F. Longchamps, Scalenie ziem zachodnich. Prawo o ustroju administracyjnym polskiej ludności miejscowej i osadnictwie nierolniczym, Warszawa 1950.

110 Zob. okólnik Ministerstwa Ziem Odzyskanych z dnia 15 lipca 1946 r. Nr 82, AAN, MRiRR, sygn. 289.

111 Dz.U. z 1946 r. nr 49 poz. 279. Prace nad projektem i innymi aktami prawnymi, dotyczącymi ziem odzyskanych: AAN, MRiRR, sygn. 289, 350, 1743. Z dekretem były związane m.in. rozporządzenie Ministrów: Rolnictwa i Reform Rolnych, Ziem Odzyskanych oraz Administracji Publicznej z dnia 22 listopada 1947 r. wydane w porozumieniu z Ministrami Obrony Narodowej i Skarbu w sprawie norm obszarowych, szacunku, odliczenia od ceny na rzecz osadników wojskowych oraz spłaty należności za gospodarstwa, nadane na podstawie dekretu z dnia 6 września 1946 r. o ustroju rolnym i osadnictwie na obszarze Ziem Odzyskanych i b. Wolnego Miasta Gdańska (Dz.U. z 1946 r. nr 74 poz. 471); rozporządzenie Ministrów: Ziem Odzyskanych, Administracji Publicznej, Rolnictwa i Reform Rolnych, Skarbu oraz Odbudowy z dnia 14 października 1947 r. wydane w porozumieniu z Ministrem Leśnictwa w sprawie włączeń i wydzieleń z zapasu ziemi na obszarze Ziem Odzyskanych i byłego Wolnego Miasta Gdańska (Dz.U. z 1947 r. nr 70 poz. 433); dekret z dnia 28 października 1947 r. o mocy prawnej ksiąg wieczystych na obszarze Ziem Odzyskanych i b. Wolnego Miasta Gdańska (Dz.U. z 1947 r. nr 66 poz. 410); pismo okólne z dnia 24 czerwca 1948 r. (UR/2 XO.44) w sprawie stosowania instrukcji z dnia 12 maja 1948 r. (Dz.Urz. Ministerstwa Rolnictwa i Reform Rolnych nr 17 poz. 64); zarządzenie Ministra Rolnictwa i Reform Rolnych z dnia 7 czerwca 1948 r. w sprawie spłat należności Państwowego Funduszu Ziemi na obszarze Ziem Odzyskanych i b. Wolnego Miasta Gdańska (Dz.Urz. Ministerstwa Rolnictwa i Reform Rolnych nr 18 poz. 65).

112 Dz.U. z 1946 r. nr 13 poz. 87. Wcześniejsza regulacja: ustawa z dnia 6 maja 1945 r. o majątkach opuszczonych i porzuconych (Dz.U. z 1945 r. nr 17 poz. 97). Zob. R. Łyczywek, Nabywanie mienia poniemieckiego na Ziemiach Odzyskanych, „Państwo i Prawo” 1948, z. 12; J. Namitkiewicz, A. Rakower, Ustawa o majątkach opuszczonych i porzuconych. Komentarz, Łódź 1945. Sprawy oraz regulacje prawne tego dotyczące: AAN, MRiRR, sygn. 1884, 1885; AAN, MS, sygn. 2600. Orzecznictwo sądowe: uchwała całej Izby Cywilnej z dnia 24 maja 1956 r. z uzupełnieniem wprowadzonym uchwałą z dnia 26 października 1956 r. (1 CO 9/56), uchwała składu siedmiu sędziów z dnia 5 listopada 1945 r. (C I 110/46); uchwała składu siedmiu sędziów z dnia 14 maja 1948 r. 
niższej rangi związanymi z akcją osadniczą na tzw. Ziemiach Odzyskanych ${ }^{113}$. Warto jednak zaznaczyć, że na cele reformy rolnej były także przeznaczone majątki poniemieckie na obszarze tzw. ziem dawnych, czyli na terenie państwa polskiego w granicach sprzed 1 września 1939 r. Do 1 stycznia 1949 r., jak podał Henryk Słabek, przejęto na tych ziemiach 89750 gospodarstw ponie-

(C III 1621/47); uchwała składu siedmiu sędziów z dnia 22 stycznia 1949 r. (C. Prez. 614/48), [w:] Orzecznictwo Sądu Najwyższego w składach powiększonych..., op.cit., poz. 25, 34, 38, 46.

113 Zob. zarządzenie Ministra Rolnictwa i Reform Rolnych z dnia 8 września 1945 r. w sprawie uregulowania przydziału gruntów gospodarstw poniemieckich (Dz.Urz. Ministerstwa Rolnictwa i Reform Rolnych nr 2 poz. 25); pismo okólne z dnia 22 lutego 1946 r. (Nr 6739/UR/P/2) w sprawie zaświadczeń PUZ o zrzeczeniu się ziemi przy wyjazdach na tereny odzyskane (Dz.Urz. Ministerstwa Rolnictwa i Reform Rolnych nr 6, poz. 80); pismo okólne z dnia 13 kwietnia 1946 r. (Nr UR/2-II-1/24) w sprawie właściwego wykonywania postanowień zarządzenia z dnia 8 września 1945 r. (Dz.U.M.R.iR.R. nr 2 poz. 25) o uregulowania przydziału gruntów gospodarstw poniemieckich (Dz.Urz. Ministerstwa Rolnictwa i Reform Rolnych nr 6 poz. 83); okólnik Nr 10 z dnia 5 czerwca 1946 r. (Nr UR/2.II.1/22) w sprawie osadnictwa na ziemiach odzyskanych (Dz.Urz. Ministerstwa Rolnictwa i Reform Rolnych nr 7 poz. 91); okólnik Nr 12 z dnia 6 czerwca 1946 r. ( $\mathrm{Nr}$ UR/2.II.1/31) w sprawie regulacji przydziału gospodarstw poniemieckich (Dz.Urz. Ministerstwa Rolnictwa i Reform Rolnych nr 7 poz. 93); zarządzenie Ministra Ziem Odzyskanych i Ministra Rolnictwa i Reform Rolnych z dnia 12 listopada 1946 r. o osadnictwie pracowniczo-parcelacyjnym (Dz.Urz. Ministerstwa Rolnictwa i Reform Rolnych nr 3 poz. 24); zarządzenie Ministra Ziem Odzyskanych z dnia 31 grudnia 1946 r. wydane w porozumieniu z Ministrem Rolnictwa i Reform Rolnych w przedmiocie częściowej zmiany zarządzenia z dnia 27 sierpnia 1946 r. w sprawie prowadzenia czynności przygotowawczych do uregulowania prawa własności w osadnictwie rolnym na obszarze Ziem Odzyskanych (Dz.Urz. Ministerstwa Rolnictwa i Reform Rolnych nr 3 poz. 25); zarządzenie Ministra Rolnictwa i Reform Rolnych z dnia 10 maja 1946 r. (Nr UR/2.I.1/103) w sprawie akcji przesiedleńczej ludności rolniczej i akcji osadnictwa rolniczego na terenach odzyskanych (Dz.Urz. Ministerstwa Rolnictwa i Reform Rolnych nr 6 poz. 74); zarządzenie Ministra Rolnictwa i Reform Rolnych z dnia 8 listopada 1947 r. w sprawie kontroli przydziału gospodarstw poniemieckich na Ziemiach Dawnych (Dz.Urz. Ministerstwa Rolnictwa i Reform Rolnych nr 12 poz. 107); rozporządzenie Ministrów: Rolnictwa i Reform Rolnych, Ziem Odzyskanych oraz Administracji Publicznej z dnia 22 listopada 1947 r. wydane w porozumieniu z Ministrami Obrony Narodowej i Skarbu w sprawie norm obszarowych, szacunku, odliczenia od ceny na rzecz osadników wojskowych oraz spłaty należności za gospodarstwa, nadane na podstawie dekretu z dnia 6 września 1946 r. o ustroju rolnym i osadnictwie na obszarze Ziem Odzyskanych i b. Wolnego Miasta Gdańska (Dz.Urz. Ministerstwa Rolnictwa i Reform Rolnych nr 14 poz. 119); zarządzenie Ministrów: Rolnictwa i Reform Rolnych oraz Ziem Odzyskanych z dnia 13 grudnia 1947 r. w sprawie norm obszarowych dla gospodarstw (działek) na terenie Ziem Odzyskanych (Dz.Urz. Ministerstwa Rolnictwa i Reform Rolnych nr 14 poz. 120); instrukcja Ministerstwa Rolnictwa i Reform Rolnych z dnia 12 maja 1948 r. wydana w porozumieniu z Ministrami Ziem Odzyskanych, Odbudowy i Leśnictwa o regulacji gruntów na obszarze Ziem Odzyskanych oraz byłego Wolnego Miasta Gdańska (Dz.Urz. Ministerstwa Rolnictwa i Reform Rolnych nr 12 poz. 49); instrukcja Ministerstwa Rolnictwa i Reform Rolnych z dnia 12 maja 1948 r. wydana w porozumieniu z Ministrami Ziem Odzyskanych, Odbudowy i Leśnictwa o regulacji gruntów na obszarze Ziem Odzyskanych oraz byłego Wolnego Miasta Gdańska (Dz.Urz. Ministerstwa Rolnictwa i Reform Rolnych nr 17 poz. 63). 
mieckich, najwięcej w Poznańskiem (31,5\%), Bydgoskiem (26,1\%), Łódzkiem $(14 \%)$ oraz Warszawskiem $(10,6 \%)^{114}$.

Wielkość gospodarstw osadniczych, zgodnie z dekretem z dnia 6 września 1946 r., wynosiła od 7 do 15 ha, gospodarstw hodowlanych do 20 ha, przy czym inaczej została określona ze względu na klasę szacunkową gleby. Poza tym dekret przewidywał możliwość tworzenia gospodarstw ogrodniczych, osad rybackich i leśnych, działek pracowniczych, rzemieślniczych o określonym obszarze ${ }^{115}$. Inna była także procedura nadawania ziemi w porównaniu z dekretem o reformie rolnej. W przypadku reformy rolnej akt nadania ziemi przenosił własność, a wpis do księgi wieczystej miał charakter deklaratoryjny (potwierdzający). W dekrecie o ustroju rolnym i osadnictwie na obszarze Ziem Odzyskanych i byłego Wolnego Miasta Gdańska można było wyróżnić trzy fazy:

1) wprowadzenie osadnika w posiadanie gospodarstwa i wydanie aktu nadania przez komisję osadnictwa rolniczego, co dawało jedynie prawo do posiadania ziemi i jej użytkowania, w tym stanowiło ekspektatywę uzyskania prawa własności;

2) oszacowanie i ustalenie ceny nabycia gospodarstwa, zgodne z ceną określoną w dekrecie o reformie rolnej, przy czym różnice wynikały z szacunku budynków, zarachowania repatriantom na poczet ceny wartość mienia pozostawionego za granicami ówczesnego państwa polskiego ${ }^{116}$, przyznania specjalnych ulg osadnikom wojskowym ${ }^{117}$;

3) ostatnia faza kończyła się orzeczeniem o wykonaniu aktu nadania, wydanym przez organ administracji ogólnej I instancji; po zniesieniu w 1946 r. urzędów ziemskich był to starosta, a po zniesieniu w 1950 r. urzędu starosty i wojewody - właściwe prezydium rady narodowej szczebla powiatowego ${ }^{118}$; orzeczenie

114 Zob. H. Słabek, Polityka agrarna PPR. Geneza, realizacja, konsekwencje, Warszawa 1967, s. 323-324, Warszawa 1978, s. 296.

${ }^{115}$ Zob. A. de Saint-Ouën, O ustroju rolnym i osadnictwa na obszarze Ziem Odzyskanych i bytego Wolnego Miasta Gdańska, „Śląsko-Dąbrowski Przegląd Administracyjny” 1946, nr 11-12; A. Bielski, Ustrój rolny i osadnictwo na ziemiach odzyskanych, „Rada Narodowa” 1946, nr 45-46; N. Kołomejczyk, B. Syzdek, Polska w latach 1944-1949. Zarys Historii Politycznej, Warszawa 1971, s. 147-149.

116 Było to związane z zawarciem tzw. umów republikańskich; w dniu 9 września $1944 \mathrm{r}$. przez PKWN z rządami: Ukraińskiej Socjalistycznej Republiki Radzieckiej oraz Białoruskiej Socjalistycznej Republiki Radzieckiej, oraz w dniu 22 września 1944 r. z rządem Litewskiej Socjalistycznej Republiki Radzieckiej. Osadnictwo repatriantów dotyczyło także tzw. ziem dawnych. Zob. H. Słabek, O zasadach nadziału gospodarstw rolnych dla repatriantów na ziemiach dawnych, „Przegląd Historyczny” 1964, t. LV, z. 3; H. Słabek, Osadnictwo rolne repatriantów na ziemiach dawnych po 1944 r., „Kwartalnik Historyczny” 1964, rocznik LXXI, z. 2.

117 Zob. K. Kersten, Osadnictwo wojskowe w 1945 roku. Próba charakterystyki, „Przegląd Historyczny" 1964, t. LV, z. 4.

118 Zob. ustawę z dnia 20 marca 1950 r. o terenowych organach jednolitej władzy państwowej (Dz.U. z 1950 r. nr 14 poz. 130). 
o wykonaniu aktu nadania przenosiło własność gospodarstwa (działki) na nabywcę oraz stanowiło tytuł do ujawnienia prawa własności nieruchomości w księdze wieczystej ${ }^{119}$.

Tryb ten wynikał przede wszystkim z konieczności szybkiego zasiedlania i zagospodarowania przez ludność napływową nowych ziem, a także z dużej płynności stosunków osadniczych, np. zwiększanie areału czy opuszczanie gospodarstw. Ponadto był związany z rozpoczętą kolektywizacją rolnictwa na tym obszarze. Ostatecznie sprawę unormował dekret z dnia 6 września 1951 r. o ochronie i uregulowaniu własności osadniczych gospodarstw chłopskich na obszarze Ziem Odzyskanych ${ }^{120}$. Dekret uwłaszczał wszystkich osadników, którzy w dniu jego wejścia w życie posiadali gospodarstwa i uprawiali je osobiście. Uwłaszczenie następowało ex lege i dotyczyło gospodarstw do 15 ha użytków rolnych (gospodarstwa hodowlane - 20 ha). Należy zaznaczyć, że granice gospodarstw często były dość płynne i dlatego dekret przewidywał określenie i wydawanie orzeczeń o wykonaniu aktu nadania, przy czym dla uwłaszczonych rolników decyzje te miały mieć charakter tylko deklaratoryjny, umożliwiający wpis do księgi wieczystej. Dekret wprowadzał zmianę paralelną z dekretem o reformie rolnej, ponieważ nowi osadnicy, którzy otrzymali ziemie po jego wejściu w życie, uzyskiwali własność $\mathrm{z}$ chwilą wydania aktu nadania. $\mathrm{Z}$ dekretem wiązało się m.in. zarządzenie Ministra Rolnictwa z 12 września 1951 r. w sprawie regulacji gospodarstw osadniczych na obszarze Ziem Odzyskanych ${ }^{121}$. Normowało ono w zasadzie tzw. postępowanie regulacyjne, obejmujące całą jednostkę osadniczą, a sama procedura przypominała postępowanie scaleniowe.

5. Wymienione regulacje prawne z zakresu reformy oraz osadnictwa rolnego miały charakter rudymentarny. Warto jednak zaznaczyć, że nie wyczerpywały one w całości regulacji dotyczących przekształceń własnościowych na polskiej wsi. W związku z tym w dniu 5 września 1947 r. został wydany dekret o przejściu na własność Państwa mienia pozostałego po osobach przesiedlonych do Z.S.R.R. ${ }^{122}$, który dotyczył przejęcia przez państwo bez odszkodowania mienia osób przesiedlonych do ZSRR, oraz dekret z dnia 27 lipca 1949 r. o przejęciu na własność Państwa nie pozostających w faktycznym władaniu

119 Szerzej: J. Paliwoda, Przebudowa..., op.cit., s. 121 i n.

${ }^{120}$ Dz.U. z 1951 r. nr 46 poz. 340. Zob. T. Rek, Ochrona własności chłopskiej na Ziemiach Odzyskanych, „Nowe Prawo” 1951, nr 12; S. Breyer, Dokumentacja własności osadniczej na ziemiach odzyskanych, „Nowe Prawo” 1954, nr 1; J. Marowski, Problematyka prawna użytkowania gruntów rolnych, Warszawa 1959, s. 126 i n.; sprawozdania związane z wykonaniem dekretu: AAN, MRiRR, sygn. 1743.

${ }^{121}$ Dz.Urz. Ministerstwa Rolnictwa nr 14 poz. 87.

122 Dz.U. z 1947 r. nr 59 poz. 318. Zob. H. Słabek, Wieś i rolnictwo, op.cit., s. 205-207. 
właścicieli nieruchomości ziemskich, położonych w niektórych powiatach województwa białostockiego, lubelskiego, rzeszowskiego i krakowskiego ${ }^{123}$. Ponadto należy zwrócić uwagę na kwestię nacjonalizacji lasów o obszarze przekraczającym 25 ha, na podstawie dekretu PKWN z dnia 12 grudnia $1944 \mathrm{r}$. o przejęciu niektórych lasów na własność Skarbu Państwa ${ }^{124}$. Osobne unormowanie $\mathrm{z}$ zakresu nacjonalizacji lasów powodowało w praktyce spory o właściwość między organami ministerstwa rolnictwa i reform rolnych a ministerstwa leśnictwa ${ }^{125}$. Następną regulacją była ustawa z dnia 20 marca 1950 r. o przejęciu przez Państwo dóbr martwej ręki, poręczeniu proboszczom posiadania gospodarstw rolnych i utworzeniu Funduszu Kościelnego ${ }^{126}$. Zgodnie z arengą stanowiła ona wykonanie postanowień dekretu PKWN z dnia 6 września 1944 r. o przeprowadzeniu reformy rolnej, zgodnie z którymi „o położeniu prawnym nieruchomości ziemskich, należących do kościoła katolickiego lub gmin wyznaniowych innych wyznań, orzeknie Sejm Ustawodawczy”, zaś celem ustawy miało być usunięcie pozostałości przywilejów obszarniczo-feudalnych w dobrach martwej ręki oraz materialne zabezpieczenie duchowieństwa, co wiązało się w szczególności z utworzeniem Funduszu Kościelnego. Ustawa generalnie rozciągnęła na dobra kościelne przepisy o reformie rolnej, przejmując je bez odszkodowania na własność Państwa na zasadach w niej określonych ${ }^{127}$. Podobnie rzecz miała się $\mathrm{z}$ majątkiem zniesionych fundacji, na podstawie dekretu z 1952 r. ${ }^{128}$ Istotne znaczenie miał także dekret z dnia 18 kwietnia 1955 r. o uwłaszczeniu i o uregulowaniu innych spraw, związanych z reformą rolną i osadnictwem rolnym ${ }^{129}$. Dekret dotyczył m.in. uwłasz-

${ }_{123}$ Dz.U. z 1949 r. nr 46 poz. 339. Zob. J. Paliwoda, Przebudowa ..., op.cit., s. 54 i n.

124 Dz.U. z 1944 r. nr 15 poz. 82. Także ustawa z dnia 18 listopada 1948 r. o przejściu na własność Państwa niektórych lasów i innych gruntów samorządowych (Dz.U. z 1948 r. nr 57 poz. 456). Zob. Reforma rolna. Przejęcie lasów na własność skarbu państwa, Łódź 1945; T. Swinarski, Reforma rolna i upaństwowienie lasów a prawo łowieckie, „Gazeta Administracji” 1946, Nr 2-3; E. Stankiewicz, Polskie prawodawstwo leśne, Warszawa 1951, s. 5 i n.; E. Stankiewicz, Polskie prawodawstwo leśne, Warszawa 1971, s. 24 i n.; L. Jastrzębski, Kierunki polityki leśnej w Polsce w latach 1918-1988 (na podstawie najważniejszych aktów normatywnych), „Sylwan” 1991, nr 1-3, s. 49 i n.

125 Zob. AAN, Ministerstwo Leśnictwa, sygn. 770, 790.

${ }_{126}$ Dz.U. z 1950 r. nr 9 poz. 87. Zob. ustawa z dnia 20 marca 1950 r. o przejęciu przez państwo dóbr martwej ręki, poręczeniu proboszczom posiadania gospodarstw rolnych i utworzeniu funduszu kościelnego, „Rada Narodowa” 1950, Nr 6-7; S. Gołębiowski, Z problematyki reformy rolnej gruntów kościelnych w Polsce w latach 1918-1950, „Nowe Prawo” 1967.

127 Zob. AAN, MRiRR, sygn. 1522-1524.

${ }^{128}$ Dekret z dnia 24 kwietnia 1952 r. o zniesieniu fundacji (Dz.U. z 1952 r. nr 25 poz. 172).

129 Dz.U. z 1955 r. nr 18 poz. 107. T.j.: Obwieszczenie Ministra Rolnictwa z dnia 30 stycznia 1959 r. w sprawie ogłoszenia jednolitego tekstu dekretu z dnia 18 kwietnia 1955 r. o uwłaszczeniu i o uregulowaniu innych spraw, związanych z reformą rolną i osadnictwem rolnym (Dz.U. z 1959 r. nr 14 poz. 78). Szerzej: AAN, MS, sygn. 2595, 3592; S. Breyer, Uporzadkowanie chtopskiej własności ziemi w świetle uchwat II Zjazdu PZPR i II Plenum KC PZPR, „Państwo i Prawo” 1954; J. Ma- 
czenia dzierżawców nieruchomości państwowych, przedwojennych nabywców gruntów obszarniczych, repatriantów oraz ludności autochtonicznej na tzw. Ziemiach Odzyskanych.

Ostatecznie, z prawnego punktu widzenia, okres reformy rolnej zasadniczo zamknęły regulacje wydane na wiosnę $1958 \mathrm{r}$. W szczególności była to ustawa z dnia 12 marca 1958 r. o sprzedaży państwowych nieruchomości rolnych oraz uporządkowaniu niektórych spraw, związanych z przeprowadzeniem reformy rolnej i osadnictwa rolnego ${ }^{130}$. Odtąd zbycie nieruchomości państwowych miało odbywać się w trybie cywilnoprawnym, a nie administracyjnym. Na własność państwa przeszły nieruchomości, które były w posiadaniu państwa bez tytułu prawnego, w tym wygasły uprawnienia osób, które mogły ubiegać się o nadanie nieruchomości rolnej, a co za tym idzie sprzedaż państwowych nieruchomości rolnych, nadawanych dotychczas w trybie dekretów o przeprowadzeniu reformy rolnej oraz o ustroju rolnym i osadnictwie na obszarze Ziem Odzyskanych i byłego Wolnego Miasta Gdańska, miała odbywać się zgodnie z wymienioną wyżej ustawą. Warto dodać, że wcześniejsza ustawa $-\mathrm{z}$ dnia 13 lipca 1957 r. o obrocie nieruchomościami rolnymi ${ }^{131}$ - złagodziła zasady ograniczające obrót tymi nieruchomościami. Innym aktem prawnym była ustawa z dnia 12 marca 1958 r. o umorzeniu niektórych długów i ciężarów ${ }^{132}$. Na podstawie regulacji zostały umorzone wszelkie długi i ciężary, które były m.in. zabezpieczone na nieruchomościach ziemskich przejętych na własność państwa $\mathrm{w}$ związku z reformą rolną, przejęciem niektórych lasów, a także wygasły wszelkie roszczenia $z$ tytułu m.in. przejęcia przez państwo inwentarza, zapasów, zasiewów, upraw, szkód poniesionych z powodu pogorszenia stanu nieruchomości, bezumownego użytkowania przez jednostki państwowe gospodarstw rolnych, w tym szkód w lasach przejętych w posiadanie państwa, a następnie zwróconych właścicielom.

rowski, op.cit., s. 168 i n.; H. Starczewski, Prywatne poprawki do państwowej reformy, „Prawo i Życie" 1962, nr 8; J. Paliwoda, Przebudowa ..., op.cit., s. 63 i n.

${ }^{130}$ Dz.U. z 1958 r. nr 17 poz. 71. T. j.: Obwieszczenie Ministra Rolnictwa, Leśnictwa i Gospodarki Żywnościowej z dnia 20 października 1989 r. w sprawie ogłoszenia jednolitego tekstu ustawy z dnia 12 marca 1958 r. o sprzedaży nieruchomości Państwowego Funduszu Ziemi oraz uporządkowaniu niektórych spraw związanych z przeprowadzeniem reformy rolnej i osadnictwa rolnego (Dz.U. z 1958 r. nr 58 poz. 348). Tytuł ustawy zmieniony na podstawie: art. 1 pkt 1 ustawy z dnia 24 lutego 1989 r. o zmianie ustawy o sprzedaży państwowych nieruchomości rolnych oraz uporządkowaniu niektórych spraw związanych z przeprowadzeniem reformy rolnej i osadnictwa rolnego (Dz.U. z 1989 r. nr 10 poz. 56); art. 58 pkt 1 ustawy z dnia 19 października 1991 r. o gospodarowaniu nieruchomościami rolnymi Skarbu Państwa oraz o zmianie niektórych ustaw (Dz.U. z 1991 r. nr 107 poz. 464). Zob. J. Paliwoda, Przebudowa..., op.cit., s. 80 i n.

131 Dz.U. z 1957 r. nr 39 poz. 172. Zob. H. Świątkowski, Niektóre zagadnienia..., op.cit.;

S. Breyer, Zagadnienie uporządkowania własności chtopskiej, „Państwo i Prawo” 1959.

132 Dz.U. z 1958 r. nr 17 poz. 72 . Zob. AAN, MS, sygn. 2594. 


\section{PODSUMOWANIE}

Reforma rolna rozpoczęta w 1944 r., a zakończona formalnie w 1958 r., W istotny sposób zmieniła strukturę agrarną państwa polskiego, powstałego po drugiej wojnie światowej. W latach 60 . szacowano, że 30\% ziemi chłopskiej pochodzi właśnie z reformy rolnej. Do końca zaś 1949 r. nadano 6.070 .100 ha dla 1.068 .400 rodzin. $Z$ tego w trybie reformy rolnej: 2.384 .400 ha dla 601.500 rodzin, a w trybie osadnictwa 3.685 .700 dla 466.900 rodzin $^{133}$. Warto zaznaczyć, że zmiana struktury własnościowej ziemi inaczej kształtowała się na tzw. ziemiach dawnych (wchodzących w skład państwa polskiego sprzed 1 września 1939 r.), a inaczej na obszarze tzw. Ziem Odzyskanych (Warmia, Śląsk, Pomorze Zachodnie). Przedstawiają to poniższe tabele 1 i 2.

Tabela 1. Zmiany struktury agrarnej na Ziemiach Dawnych w latach $1939-1950$

(gospodarstwa $0-50$ ha)

\begin{tabular}{|c|c|c|c|}
\hline \multirow{2}{*}{$\begin{array}{c}\text { Grupy gospodarstw } \\
\text { (w ha) }\end{array}$} & \multicolumn{2}{|c|}{$\begin{array}{c}\text { Liczba gospodarstw } \\
\text { (w tysiącach) }\end{array}$} & \multirow{2}{*}{$\begin{array}{c}\text { Zmiany w \% } \\
\text { (1939=100) }\end{array}$} \\
\cline { 2 - 3 } & $\mathbf{I ~ 1 9 3 9}$ & XII 1950 & \\
\hline $\mathbf{0}-\mathbf{2}$ & 783,1 & 683,0 & 87,2 \\
\hline $\mathbf{2}-\mathbf{5}$ & 781,5 & 902,0 & 115,4 \\
\hline $\mathbf{5}-\mathbf{1 0}$ & 617,1 & 746,9 & 121,0 \\
\hline $\mathbf{1 0}-\mathbf{2 0}$ & 262,1 & 249,0 & 95,0 \\
\hline Powyżej 20 & 57,5 & 34,1 & 59,3 \\
\hline Ogółem & $\mathbf{2 5 0 1 , 3}$ & $\mathbf{2 ~ 6 1 5 , 0}$ & $\mathbf{1 0 4 , 6}$ \\
\hline
\end{tabular}

Źródło: M. Mieszczankowski, Struktura agrarna Polski międzywojennej, Warszawa 1960, s. 400; W. Góra, Reforma rolna PKWN, Warszawa 1969, s. 253.

133 Rolniczy Rocznik Statystyczny 1945-1965, Warszawa 1966, s. 115; Rocznik Statystyczny 1948, Warszawa 1949, s. 39-42; Rocznik Statystyczny 1949, Warszawa 1950, s. 54-59; Rocznik Statystyczny 1955, Warszawa 1956, s. 104; Rocznik Statystyczny 1959, Warszawa 1959, s. 184. Zob. W. Michna, A. Szynkarczuk, Rolnictwo..., op.cit., s. 38-40; W. Góra, H. Słabek, Polityka rolna władzy ludowej w latach 1944-1948, op.cit., s. 180-183; B. Głębowicz, Przemiany stosunków agrarnych w Polsce w latach 1944-1965, „Zeszyty Naukowe Uniwersytetu Mikołaja Kopernika w Toruniu. Nauki Humanistyczno-Społeczne”, Toruń 1967, z. 22, Nauki Polityczne I; W. Góra, Reforma rolna PKWN, op.cit., s. 239 i n.; H. Słabek, Wieś i rolnictwo, op.cit., s. 214-221; H. Słabek, Reforma rolna op.cit., s. 60-70; A. Suchoń, Ekonomiczne aspekty reformy rolnej i osadnictwa, [w:] Reformy rolne w Polsce międzywojennej i powojennej..., op.cit. 
Tabela 2. Zmiany w strukturze agrarnej Ziem Odzyskanych w stosunku do 1939 r.

\begin{tabular}{|c|c|c|c|c|c|c|}
\hline \multirow{2}{*}{$\begin{array}{c}\text { Grupy } \\
\text { gospodarstw } \\
\text { (w ha) }\end{array}$} & \multicolumn{2}{|c|}{1939} & \multicolumn{2}{|c|}{1950} & \multirow{2}{*}{$\begin{array}{c}\text { Zmiany } \\
\text { w ilości gospo- } \\
\text { darstw w \% } \\
(1939=100)\end{array}$} & \multirow{2}{*}{$\begin{array}{c}\text { Różnica } \\
\text { w punktach } \\
\text { (w stosunku } \\
\text { do } 1939 \text { r.) }\end{array}$} \\
\hline & $\begin{array}{l}\text { Ilość go- } \\
\text { spodarstw } \\
\text { (w tys.) }\end{array}$ & $\%$ & $\begin{array}{l}\text { Ilość go- } \\
\text { spodarstw } \\
\text { (w tys.) }\end{array}$ & $\%$ & & \\
\hline $0,5-2$ & 112,9 & 23,6 & 99,3 & 19,3 & 88,0 & $-4,3$ \\
\hline $2-5$ & 89,1 & 18,7 & 89,8 & 17,4 & 100,8 & $-1,3$ \\
\hline $5-10$ & 104,7 & 22,0 & 229,7 & 44,7 & 219,4 & $+22,7$ \\
\hline $10-20$ & 101,7 & 21,3 & 90,0 & 17,5 & 88,5 & $-3,8$ \\
\hline $20-100$ & 67,4 & 14,4 & 5,7 & 1,1 & 8,4 & $-13,3$ \\
\hline Ogólem & 475,8 & 100,0 & 514,5 & 100,0 & 108,1 & - \\
\hline
\end{tabular}

Źródło: Rocznik Statystyczny 1947, Warszawa 1947, s. 39-40; W. Góra, Reforma rolna PKWN, Warszawa 1969, s. 256.

W porównaniu z innymi ówczesnymi krajami socjalistycznymi państwo polskie przekazało najwięcej ziemi chłopom - 6.070.100 tys. ha. Inne natomiast państwa przekazały odpowiednio: Czechosłowacja - 1290,5 tys. ha; Jugosławia 797 tys. ha; Rumunia - 1 111,0 tys. ha; Węgry -1 875,3 tys. ha; Bułgaria - 137,0 tys. ha ${ }^{134}$. Szczegółowe dane przedstawia tabela 3.

Tabela 3. Ogólne wyniki reformy rolnej w krajach demokracji ludowej

\begin{tabular}{|l|c|c|c|c|c|}
\hline \multicolumn{1}{|c|}{ Kraj } & $\begin{array}{c}\text { Obszar ogól- } \\
\text { ny (w tys. } \\
\mathbf{k m}^{2} \text { ) }\end{array}$ & $\begin{array}{c}\text { Obszar ziem } \\
\text { przekaza- } \\
\text { nych chło- } \\
\text { pom } \\
\text { (w tys. ha) }\end{array}$ & $\begin{array}{c}\text { Stosunek } \\
\text { rozparcelo- } \\
\text { wanych ziem } \\
\text { do ogólnej } \\
\text { powierzchni } \\
\text { (\%) }\end{array}$ & $\begin{array}{c}\text { Liczba par- } \\
\text { celantów } \\
\text { w tys. }\end{array}$ & $\begin{array}{c}\text { Przeciętnie } \\
\text { na 1 gospo- } \\
\text { darstwo } \\
\text { (w ha) }\end{array}$ \\
\hline Polska & 312,5 & 6070,1 & 19,4 & 1068,4 & 5,7 \\
\hline Albania & 28,7 & 172,0 & 5,9 & 70,2 & 2,5 \\
\hline Bulgaria & 110,8 & 150,0 & 1,4 & 128,8 & 1,2 \\
\hline Czechosłowacja & 127,9 & 1220,7 & 9,5 & 303,4 & 4,0 \\
\hline Jugosławia & 256,0 & 797,0 & 3,1 & 316,4 & 2,5 \\
\hline NRD & 107,8 & 2190,0 & 20,3 & 559,1 & 3,9 \\
\hline Rumunia & 237,5 & 1111,0 & 4,7 & 918,9 & 1,2 \\
\hline Węgry & 93,0 & 1875,3 & 20,1 & 642,3 & 3,0 \\
\hline
\end{tabular}

Źródło: W. Góra, Reforma rolna PKWN, Warszawa 1969, s. 250.

${ }_{134}$ Zob. A. Petrušov, Sel'skoe hozâjstvo evropejskih stran narodnoj demokratii na socialističeskom puti, Moskwa 1959, s. 46-69; A. Pietruszow, Przeobrażanie rolnictwa w krajach demokracji ludowej, Warszawa 1950, s. 6-10; W. Góra, Reforma rolna PKWN, op.cit., s. 250-251; Reformy agrarne.., op.cit., s. 32. 
Ponadto istotne znaczenie miał fakt, że reformy rolne poza tzw. aspektami antyfeudalnymi (antyobszarniczymi) miały także charakter antyniemiecki. W areale bowiem PFZ w Polsce, ale i w Czechosłowacji oraz Jugosławii poważny odsetek stanowiły grunty poniemieckie. Stanowiły one odpowiednio w Polsce $-75,7 \%$; Czechosłowacji - 70,8\%; Jugosławii - 40,8\% ${ }^{135}$.

Kluczowe znaczenie miały cechy konstytutywne ustawodawstwa dotyczącego reformy rolnej. Zaliczyć do nich należy przede wszystkim:

1) akty prawne wydawane były w większości przez władzę wykonawczą, w postaci dekretów PKWN, opartych na Manifeście PKWN oraz w praktyce „mglistych” zasadach konstytucji z 1921 r. ${ }^{136}$;

2) wykonanie reformy zależało w rzeczywistości od organów ówczesnej administracji, co w praktyce oznaczało, że regulacje rangi ustawowej mają charakter ramowy, a o przebiegu reformy decydują akty niższego rzędu, np. okólniki, pisma, zarządzenia, instrukcje, wytyczne, wskazówki wydawane przez organy administracji, w tym partie polityczne, w szczególności Polską Partię Robotniczą ${ }^{137}$;

3) tryb przeprowadzenia reformy rolnej miał charakter administracyjny, bez możliwości odwołania się do sądów powszechnych czy administracyjnych; w praktyce oznaczało to brak sądowej kontroli decyzji administracyjnych;

4) w zasadzie nie była uregulowana indemnizacja wywłaszczonych obszarników - właścicieli ziemskich, których pozycja społeczna uległa degradacji;

5) rolnicy otrzymali nadziały ziemi na wyjątkowo korzystnych warunkach finansowych;

6) istotne różnice w zakresie przeprowadzenia reformy rolnej dotyczyły poszczególnych obszarów ówczesnego państwa polskiego, w szczególności osadnictwa na tzw. Ziemiach Odzyskanych ${ }^{138}$.

135 H. Słabek, Dzieje polskiej reformy rolnej 1944-48, Warszawa 1972, s. 290. Szerzej: H. Słabek, Polityka agrarna PPR (Geneza i realizacja), Warszawa 1967, s. 525 i n.; Warszawa 1978, s. 556 i n.

136 Szerzej: M. Buszyński, Obowiązujące normy Konstytucji Marcowej, „Gazeta Administracji” 1947, nr 11-12; S. Rozmaryn, W jakim zakresie obowiazuje dziś Konstytucja z 17 marca 1921 roku, „Państwo i Prawo” 1948, z. 1; K. Działocha, J. Trzciński, Zagadnienie obowiązywania Konstytucji marcowej w Polsce Ludowej 1944-1952, Wrocław-Warszawa-Kraków-Gdańsk 1977; E. Zwierzchowski, Polityczny proces ksztattowania ustroju Polski Ludowej 1944-1952, Katowice 1981.

137 Zob. Reforma Rolna PKWN. Materiaty i dokumenty, Warszawa 1959; F. Longchamps, Prawo agrarne, Warszawa 1949, s. 25 i n.; B. Głębowicz, Realizacja reformy rolnej Polskiego Komitetu Wyzwolenia Narodowego w województwie pomorskim w latach 1945-1948, Toruń 1966, s. 22 i n.; Dz.Urz. Ministerstwa Rolnictwa i Reform Rolnych z lat 1945-48; m.in. pisma okólne departamentu przebudowy ustroju rolnego do Wojewódzkich Urzędów Ziemskich, zarządzenia Ministra Ziem Odzyskanych, Ministra Rolnictwa i Reform Rolnych, pisma okólne departamentu przebudowy ustroju rolnego, AAN, MRiRR, sygn. 440-446, 457, 1743, 1744, 3060, 4973, 4974, 5059.

${ }_{138}$ Szerzej: AAN, MRiRR, sygn. 1714, 1717, 1901; W. Góra, PPR w walce..., op.cit., s. 206 i n.; W. Góra, Reforma rolna PKWN, op.cit., s. 115 i n.; H. Słabek, Przebudowa ustroju rolne- 
Władze ówczesne często porównywały reformę rolną z okresem Polski przedwrześniowej ${ }^{139}$, w szczególności „starą reformę rolną nazwano obszarniczą, nową, tj. PKWN-u - chłopską; starą nazywano też reformą z długami, a nową nazywano reformą bez długów" ${ }^{140}$. Istotne znaczenie dla przebiegu reformy miała akcja propagandowa, posługująca się często sloganami czy wierszykami, np. „Dawniej dziedzic, gdy se golnął, krzyczał precz z reformą rolną. Dziś to grubym jest nietaktem, zaś reforma rolna faktem" ${ }^{141}$. Ponadto w ówczesnych opracowaniach dotyczących reformy rolnej, cytowano zwykle stwierdzenie Włodzimierza I. Lenina: „niechaj chłopi wiedzą, że nie może być pożytku z żadnej reformy rolnej, jeżeli sprawa będzie znajdowała się w rękach starej władzy" ${ }^{142}$. W związku z tym Bolesław Drobner na VIII sesji Krajowej Rady Narodowej explicite stwierdził, że „w żadnym wypadku wielkich wydarzeń historycznych kompromisy nie doprowadzały do celu”, a „gdybyśmy chcieli reformę rolną, konieczną dla naszego Państwa, przeprowadzić w kompromisie z obszarnikami, z reformy rolnej nic by nie zostało. Obszarnicy by ją sparaliżowali. Społeczeństwo, które chce żyć, które chce się rozwijać, musi mieć jasny cel, musi znaleźć jasną drogę i być bezkompromisowym" ${ }^{143}$. Zresztą reforma agrarna stanowiła osiągnięcie polityczno-społeczne dla ówczesnej władzy ludowej ${ }^{144}$. Dlatego w kolejne rocznice

go w Wielkopolsce i na Pomorzu 1945-1948, Poznań 1968; H. Słabek, Dzieje polskiej..., op.cit.; B. Głębowicz, Realizacja reformy rolnej Polskiego Komitetu Wyzwolenia Narodowego w województwie pomorskim w latach 1945-1948, Torun 1966; S. Iwaniak, Reforma rolna w województwie kieleckim w latach 1944-1945, Warszawa 1975; Cz. Brzoza, Reforma rolna w województwie krakowskim (1945-1948), Wrocław-Warszawa-Kraków-Gdańsk-Lódź 1988; S. Łach, Przekształcenia ustrojowo-gospodarcze $w$ rolnictwie ziem zachodnich i pótnocnych $w$ latach 1945-1949, Słupsk 1993; Z. J. Winnicki, Uwagi o efektach i zastosowaniu dekretu PKWN o przeprowadzeniu reformy rolnej w powiecie stopnickim (województwo kieleckie), „Wrocławskie Studia z Historii Najnowszej”, t. IV, red. W. Wrzesiński, Wrocław 1997; H. Duda, Początki sektora państwowego w rolnictwie na Ślasku Opolskim (marzec 1945 - luty 1946). Reforma rolna - zarys problemu, Opole 2008; J. Taraszewski, Reforma rolna na poludniowym Mazowszu w latach 1944-1947, Góra Kalwaria 2010; Ł. Skarżyński, Dekret PKWN o reformie rolnej 1944 r. na przykładzie pótnocnego Mazowsza-ziemia puttuska, „Miscellanea Historico-Iuridica” 2016, t. XV, z. 1.

139 Zob. S. Breyer, Prawo chłopów do ziemi w Polsce Ludowej, Warszawa 1955, s. 11 i n.; Cz. Madajczyk, Burżuazyjno-obszarnicza reforma..., op.cit., s. 387 i n.; M. Mieszczankowski, op.cit., s. 399 i n.; H. Świątkowski, Prawo rolne, Warszawa 1966, s. 18 i n.; A. Burda, Reformy społeczno-gospodarcze w okresie Krajowej Rady Narodowej, [w:] Krajowa Rada Narodowa, op.cit., s. 234 i n.

140 A. Szemberg, Reforma..., op.cit., s. 34.

${ }^{141}$ F. Ryszka, »Sprawa Polska«..., op.cit., s. 107.

142 W.I. Lenin, Sprawa ziemi w Dumie, Dzieła, t. 10, Warszawa 1955, s. 412. Zob. H. Słabek, Lenin a ewolucja programu agrarnego KPP, [w:] Lenin a kwestia agrarna w kapitalizmie i socjalizmie, op.cit.

${ }^{143}$ Sprawozdanie stenograficzne z VIII sesji KRN, łam 71. Zob. J. Zakrzewska, Sesje plenarne Krajowej Rady Narodowej, [w:] Krajowa Rada Narodowa, op.cit., s. 183-184.

144 Zob. materiały na wystawy krajowe i zagraniczne ilustrujące przeprowadzenie reformy rolnej, AAN, MRiRR, sygn. 2648. 
reformy ukazywały się publikacje, w których określano dekret PKWN z 1944 r. jako wydarzenie przełomowe dla polskiej wsi, kończące długotrwałą walkę mas chłopskich o ziemię ${ }^{145}$. Zaznaczano przy tym, że „główne ostrze reformy rolnej skierowane było przeciwko najbardziej reakcyjnej i najbardziej wstecznej klasie pasożytniczej - obszarnictwu, przeciwko tym, którzy reprezentowali w Polsce resztki feudalizmu"146. Poza granicami ówczesnego państwa polskiego uważano, że „nowa reforma rolna ma na widoku w pierwszej linii cele polityczne, a następnie dopiero gospodarcze"147, w szczególności wynikało to z: trybu jej przeprowadzenia, wywłaszczenia bez odszkodowania dawnych właścicieli ziemskich, tworzenia tzw. gospodarstw karłowatych, które nie były samodzielne ekonomicznie. W ostatnim wypadku powodowało to przede wszystkim problemy w produkcji rolno-towarowej ze względu na rozdrobnienie produkcji rolniczej, w szczególności w drugiej połowie lat $40 .{ }^{148}$

W książce dotyczącej X rocznicy prawa Polski Ludowej Józef Fiema i Henryk Świątkowski opisując problematykę prawną rolnictwa stwierdzili natomiast, że „reforma rolna w Polsce Ludowej (rozumiejąc przez nią i osadnictwo na Ziemiach Odzyskanych) w sposób zasadniczy różni się od »reformy« rolnej z okresu 20-lecia. Nasza reforma rolna przeprowadzona była w interesie bezrolnych, małorolnych i średniorolnych chłopów, przeciwko klasie obszarniczej w celu jej likwidacji. Reforma rolna z r. 1925 była »reformą« dla obszarnictwa i kapitalistycznych elementów wsi; dla szerokich mas biedoty wiejskiej była oszukańczym manewrem, pogłębiła nędzę tych mas”, a „otrzymawszy od władzy ludowej wolność i ziemię, chłopstwo pracujące wyzwoliło się raz na zawsze od wiekowego ucisku obszarników i kapitalistów, zespoliło się jeszcze bardziej wokół klasy robotniczej i jej partii, stało się równouprawnionym gospodarzem kraju. Przeprowadzenie reformy rolnej było ogromnym zwycięstwem całego ludu pracującego, zwycięstwem idei sojuszu robotniczo-chłopskiego, podstawy władzy w Polsce Ludowej" 149 .

Należy zaznaczyć, że regulacje o reformie rolnej, w szczególności dekrety o przeprowadzeniu reformy rolnej oraz o ustroju rolnym i osadnictwie na obszarze Ziem Odzyskanych i byłego Wolnego Miasta Gdańska, jak i inne akty prawne

145 Szerzej: W. Góra, W dziesiąta rocznicę reformy rolnej, „Nowe Drogi” 1954, nr 8; T. Kuta, $W$ dziesięciolecie reformy rolnej, „Zeszyty Naukowe Uniwersytetu Wrocławskiego im. Bolesława Bieruta”, Seria A, nr 3, 1956; F. Tomczak, $W$ dwudziestolecie Reformy Rolnej PKWN, „Nowe Rolnictwo” 1964, nr 17; S. Jarecka, W 25-lecie reformy rolnej, „Wieś Współczesna” 1969, nr 9.

146 W. Góra, $W$ dziesiąta rocznicę..., op.cit., s. 34.

147 J. Rakowski, Wczoraj i dziś reformy rolnej w Polsce, Fryburg (Szwajcaria) 1946, s. 15. Zob. D.T. Pronin, Land Reform in Poland: 1920-1945, „Land Economics”, Vol. 25, nr 2, s. 133-143.

148 Zob. A. Szemberg, Reforma..., op.cit., s. 46; H. Jędruszczak, Niektóre zagadnienia sytuacji gospodarczej Polski w latach 1945-1949, „Kwartalnik Historyczny” 1964, r. LXXI, z. 2, s. 374-378.

149 J. Fiema, H. Świątkowski, Problematyka prawna rolnictwa, op.cit., s. 243-244. 
z tego okresu, m.in. o przejęciu niektórych lasów na własność Skarbu Państwa ${ }^{150}$, o przejęciu przez Państwo dóbr martwej ręki, poręczeniu proboszczom posiadania gospodarstw rolnych i utworzeniu Funduszu Kościelnego czy dekrety: warszaw$\mathrm{ski}^{151}$ oraz nominalistyczny ${ }^{152}$, nadal są regulacjami obowiązującymi w polskim systemie prawnym. Oczywiście wymienione unormowania ekspropriacyjne były z punktu widzenia prawnego oparte na ówczesnym status quo i miały osiągnąć określony cel polityczny ${ }^{153}$. Jednak współczesne uchylenie ich czy istotna zmiana w kierunku zadośćuczynienia krzywd podmiotom poszkodowanym oznaczałaby ogromne skutki ekonomiczno-społeczne, które w przypadku reformy rolnej wiązałyby się ze zmianami własnościowymi na polskiej wsi albo wypłatą rekompensat, które obciążałyby finalnie polskich podatników. Oczywiście współcześnie sprawy z tego zakresu znajdują się w kognicji sądów polskich, w praktyce głównie administracyjnych ${ }^{154}$. Należy przy tym jednak podkreślić, że państwo polskie jest ostatnim krajem dawnego bloku państw demokracji ludowej w Europie, w którym nie została przeprowadzona reprywatyzacja, w szczególności w związku z reformą rolną ${ }^{155}$.

Podobne problemy, dotyczące rewindykacji od państwa polskiego majątków ziemskich skonfiskowanych przez byłe rządy zaborcze uczestnikom walk o odzyskanie niepodległości w latach 1830-1864 r., miały miejsce w okresie II Rzeczypospolitej ${ }^{156}$. Wówczas państwo polskie dopiero w latach 30. zdobyło

${ }^{150}$ Art. 6 ustawy z dnia 28 lipca 1990 r. o zmianie ustawy - Kodeks cywilny (Dz.U. z 1990 r. nr 55 poz. 321) uchylił dekret, przy czym pozostawił w mocy nabycie własności, które nastąpiło na jego podstawie.

${ }^{151}$ Dekret z dnia 26 października 1945 r. o własności i użytkowaniu gruntów na obszarze m. st. Warszawy (Dz.U. z 1945 r. nr 50 poz. 279).

152 Dekret z dnia 27 lipca 1949 r. o zaciąganiu nowych i określaniu wysokości nie umorzonych zobowiązań pieniężnych (Dz.U. z 1949 r. nr 45 poz. 332). Zob. R. Jastrzębski, Wpływ siły nabywczej pieniadza..., op.cit., s. $413 \mathrm{i} \mathrm{n.}$

153 Zob. Reforma rolna 1944-1945 czy komunistyczna zbrodnia? Dokumenty i materiały. Świadectwa. Wnioski, Warszawa 2009; M. Walewska, W cieniu ustawy o reformie rolnej. Wspomnienia 1944-1945, Warszawa 2007.

${ }^{154}$ Szerzej: Ł. Bielecki, Nacjonalizacja nieruchomości ziemskich na obszarze południowo wschodniego pogranicza Polski (część I), „Rejent” 2007, nr 5, (część II) „Rejent” 2007, nr 6; A. Jagielska, Reforma rolna na tle orzecznictwa Naczelnego Sadu Administracyjnego - zagadnienia wybrane, [w:] Reformy rolne w Polsce międzywojennej i powojennej..., op.cit.; A. Herman, Od PKWN do własności. Restytucja mienia przejętego dekretem reformy rolnej, Warszawa 2010; P.T. Kociubiński, op.cit., s. 323 i n.; M. Kaliński, Nieruchomość ziemska o charakterze rolniczym w świetle dekretu o przeprowadzeniu reformy rolnej (glosa do wyroku Naczelnego Sądu Administracyjnego z dnia 24 czerwca 2015 r., I OSK 2440/13), „Monitor Prawniczy” 2016, z. 2.

155 Zob. W. Szafrański, A. Jagielska, Dotychczasowe koncepcje przeprowadzenia reprywatyzacji w Polsce, [w:] Reformy rolne w Polsce międzywojennej i powojennej..., op.cit.

156 Szerzej: Konfiskaty popowstaniowe w Sązie Najwyższym, Warszawa 1929, 1930; A. Suligowski, Bezprawia i konfiskaty pod rzadami rosyjskimi, Warszawa 1928; Głosy prasy w sprawach 
się na wydanie regulacji prawnych, dotyczących zwrotu tych dóbr ${ }^{157}$. Warto jednak zaznaczyć, że przyjęte rozwiązania budziły kontrowersje, przeciwna zwrotowi majątków była zwłaszcza ówczesna Prokuratoria Generalna Rzeczypospolitej Polskiej ${ }^{158}$. Oczywiście współcześnie powrót do status quo ante, czyli uchylenie skutków prawnych reformy rolnej, jest niemożliwy ze względu na przekształcenia własnościowe oraz upływ czasu. W związku z tym reforma rolna zapoczątkowana dekretem PKWN z 1944 r. stanowi bezsprzecznie wydarzenie bezprecedensowe $\mathrm{w}$ historii państwa polskiego, którego skutki są w zasadzie nieodwracalne. Na zakończenie należy dodać, że reforma miała w Polsce Ludowej przede wszystkim charakter polityczny oraz miała stanowić wstęp do kolektywizacji rolnictwa, do której jednak ostatecznie nie doszło.

\section{LAND REFORM AFTER WORLD WAR II. LEGISLATION IN POLAND}

\section{Abstract}

Agrarian reforms in Central Europe date back to the $19^{\text {th }}$ century. They were connected with the abolition of personal serfdom, socage as well as of rentification, and ultimately granting the peasants land which they farmed previously. These reforms were carried out on the Polish lands during the partition period. As a result, the course of the changes and the resulting agrarian structure was significantly different in the territory of the Polish state that was created after the First World War. Later, a land reform was carried out in the Second Polish Republic. Initially, it was done on the basis of the Act of 15 July 1920

konfiskat popowstaniowych, Warszawa 1930; J.A. Święcicki, Rewindykacja konfiskat popowstaniowych w świetle cyfr, etyki i celowości, Warszawa 1931; J.A. Święcicki, Nowe projekty ponownej konfiskaty mienia powstańców, Warszawa 1932; A. Suligowski, Uwagi do projektu ustawy o nadaniu gruntów z dóbr skonfiskowanych przez byte rządy zaborcze, Warszawa 1931; S. Milewski, Ciemne sprawy międzywojnia, Warszawa 2002, s. 70 i n.; P. Makarzec, Rewindykacja dóbr popowstańczych w II Rzeczypospolitej, „Studia Iuridica Lublinensia” 2007, t. 10.

157 Zob. ustawa z dnia 18 marca 1932 r. o dobrach skonfiskowanych przez byłe rządy zaborcze uczestnikom walk o niepodległość (Dz.U. z 1932 r. nr 24 poz. 189); rozporządzenie Prezydenta Rzeczypospolitej z dnia 21 października 1932 r. zmieniające niektóre przepisy ustawy z dnia 18 marca 1932 r. o dobrach skonfiskowanych przez byłe rządy zaborcze uczestnikom walk o niepodległość (Dz.U. z 1932 r. nr 91 poz. 771); ustawa z dnia 14 kwietnia 1937 r. o dobrach skonfiskowanych przez byłe rządy zaborcze uczestnikom walk o niepodległość i będących w posiadaniu związków samorządowych (Dz.U. z 1937 r. nr 30 poz. 221).

158 Szerzej: Zakwalifikowanie konfiskat popowstaniowych przez Prokuratorję Generalna Rzeczypospolitej Polskiej, Warszawa 1930; J.T. Steuermark, Wniosek w sprawie Marjii Uszyckiej ze Skarbem Państwa o skonfiskowane dobra, „Gazeta Sądowa Warszawska” 1930, nr 9; S. Bukowiecki, Z rozmyślań nad sprawa procesów konfiskacyjnych, „Ruch Prawniczy, Ekonomiczny i Socjologiczny" 1932; R. Jastrzębski, Reprywatyzacja w państwie polskim z punktu widzenia historii prawa, „Studia i Analizy Sądu Najwyższego. Materiały Naukowe. Reprywatyzacja w orzecznictwie sądów”, t. III, Warszawa 2016. 
which announced the implementation of the land reform. Subsequently, the land reform was based on the Act of 28 December 1925. The final regulation which was issued was associated with the implementation of the Act of 17 March 1921 of the Polish Constitution. Its provisions deviated from those in the act of 1920. In particular, it concerned the amount of indemnity paid to landowners. The implementation of the land reform was mainly impeded during the Great Depression. This economic depression also resulted in a substantial fall in the profitability of the agricultural farms. As a consequence, the land reform did not result in significant changes in the agrarian structure of the Second Polish Republic.

During the Second World War in 1944, the Polish Committee of National Liberation issued a manifesto in which, inter alia, it announced the introduction of an agrarian reform. Subsequently, on the $6^{\text {th }}$ of September 1944, the Polish Committee of National Liberation issued a decree on the land reform. According to the aforementioned document, the purpose of the reform was to pass agricultural holdings exceeding a certain size to the ownership of the state. Moreover, this process was carried out without any compensation to the previous owners. As a result of the implementation of the land reform, the National Land Fund was established in order to manage the land holdings collected in this manner. The proceedings concerning the reform were administrative in character which effectively prevented the former landowners from filing a court case at the time. Furthermore, the agricultural reform in the so-called "Recovered Territories", which were attached to the Polish state as a result of the Potsdam Conference in 1945, was carried out in a different way. It was not until the $6^{\text {th }}$ of September 1946 that a decree was issued on the agricultural system and settlement on the lands of the Recovered Territories and the former Free City of Danzig. The decree was a special regulation relating to the Decree on Agrarian Reform. Its primary purpose was to enable the settlement of those lands as quickly as possible. Therefore, a different procedure was implemented for transferring land to the settlers in those areas. The land reform period after World War II, from a legal standpoint, ended with the release of legal acts between 1957 and 1958. It is also worth mentioning that during that period the forests and the real estate belonging to the church were separately nationalized (respectively by the 1944 decree and by the Church Estate Act of 1950). The agrarian reform, announced in the Manifesto of the Polish Committee of National Liberation, significantly changed the agrarian and social structure of the Polish state after the Second World War. It is estimated that $30 \%$ of the land made available to peasants came from the land reform. At the same time, it resulted in the decrease of the importance of the landowners. It should also be noted that the aforementioned legal regulations pertaining to the land reform remain in force in the currently binding law.

\section{RÉFORME AGRAIRE APRÈS LA SECONDE GUERRE MONDIALE. LÉGISLATION DE L'ÉTAT POLONAIS}

\section{Résumé}

Les réformes agraires en Europe centrale remontent au XIXème siècle. Elles étaient liées à l'abolition du servage personnel et de la corvée, au cens et, finalement, à l'affranchissement et à la redistribution des terres aux paysans. Sur le territoire polonais, ces 
réformes ont été menées pendant la période de partage de la Pologne. Par conséquent, leur déroulement, et aussi la structure agraire qui en résultait, étaient considérablement différents sur le territoire de l'État polonais, créé après la Première Guerre mondiale. Dans la période de la Deuxième République de Pologne, l'État a réalisé une nouvelle réforme agraire. Au début, sur la base de la loi du 15 juillet 1920 sur la mise en œuvre de la réforme agraire, puis de la loi du 28 décembre 1925. Le dernier règlement résultait de l'entrée en vigueur de la loi du 17 mars 1921, à savoir la Constitution de la République de Pologne dont les normes dérogeaient aux dispositions de la loi de 1920. Les différences concernaient surtout le montant de l'indemnisation versée au propriétaire de la terre. Le ralentissement de la mise en œuvre de la réforme s'est largement produit au cours de la grande crise économique qui a causé une baisse drastique de la rentabilité des ateliers agricoles. En conséquence, la réforme agraire n'a pas apporté de changements significatifs dans la structure agraire de la Deuxième République de Pologne.

Pendant la Seconde Guerre mondiale, en 1944, le Comité polonais de libération nationale a proclamé un manifeste dans lequel, entre autres, il a annoncé la réalisation de la réforme agraire. Puis, le 6 septembre 1944, le Comité polonais de la libération nationale a publié le décret sur la mise en œuvre de la réforme agraire, selon lequel les terres agricoles s'étendant au-dessus d'une surface déterminée, faisaient l'objet de la réforme. Les biens immobiliers devenaient la propriété de l'État sans compensation au profit des anciens propriétaires. Dans le cadre de la réalisation de la réforme agraire, on a créé le Fonds National Foncier qui gérait ces réserves de terres. La procédure liée à l'exécution de la réforme était de nature administrative, ce qui, en ce temps-là, empêchait les anciens propriétaires de s'adresser au tribunal. Sur les territoires dits Terres Récupérées, rattachés à l'État polonais suite à la conférence de Potsdam en 1945, la réforme agraire s'est déroulée d'une autre manière. Le décret sur le système agricole et l'établissement de la population dans la zone des Terres Récupérées et de l'ancienne ville libre de Gdańsk (Dantzig) a été promulgué seulement le 6 septembre 1946. Le décret constituait une disposition dérogatoire par rapport au décret sur la mise en œuvre de la réforme agraire. Son but principal était d'y établir la population le plus rapidement possible. Par conséquent, on a adopté un autre mode d'octroi de terres aux colons. Finalement, du point de vue juridique, la période de la réforme agraire après la Seconde Guerre mondiale a pris fin avec la promulgation des lois dans les années 1957 - 58. Il convient de noter que de manière séparée, au cours de cette période, les forêts ont été nationalisées avec le décret de 1944 et les biens immobiliers de l'Église avec la loi de 1950. La réforme agraire, annoncée dans le Manifeste du Comité polonais de libération nationale, a considérablement changé la structure sociale et agraire de l'État polonais après la Seconde Guerre mondiale. Dans les années 60, il a été estimé que $30 \%$ des terres paysannes provenait de la réforme agraire. D'autre part, la réforme a causé la dégradation des propriétaires fonciers. Il faut ajouter que les règlements juridiques mentionnés relatifs à la réforme agraire constituent toujours le droit applicable. 